LINDA FRANCE STINE

MELANIE A. CABAK

MARK D. GROOVER

\section{Blue Beads as African-American Cultural Symbols}

\section{ABSTRACT}

\begin{abstract}
Blue beads are consistent finds at African-American sites. Archaeologists acknowledge these artifacts were used for adornment, yet some researchers also propose beads possessed additional cultural meaning among African Americans. For this study bead data from African-American sites in the South are analyzed. The results indicate blue is the predominant bead color. The prevalence of these items suggests they may indeed have been an important yet unrecognized aspect of African-American culture. The multiple underlying meanings assigned to blue beads are considered through reference to ethnographic information, folklore, and oral history associated with West and Central Africa and the Southeast.
\end{abstract}

\section{Introduction}

Although almost always recovered in small quantities, historical archaeologists have nevertheless noted that glass beads, especially blue beads, are typical finds at African-American sites. These artifacts have been interpreted in several ways. At a minimal level, beads are considered to be merely clothing or personal artifacts. Several archaeologists suggest beads were primarily used by women (Smith 1977:160-161; Drucker and Anthony 1979: 79; Otto 1984:73, 174-175; Yentsch 1994a, 1994b) and reflect cultural practices derived from West Africa (Handler et al. 1979:15-18; Armstrong 1990:272; Yentsch 1994a, 1994b). Concerning blue beads, Ascher and Fairbanks (1971:8) suggest they are similar to trade beads highly valued in Africa. Smith (1977:161) and Otto (1984:75) propose they are ethnic markers for sites occupied by African Americans. Adams (1987:14) argues blue beads were symbolically meaningful artifacts for slaves between the 18th and 19th centuries. An alternative interpretation is that the cultural meaning assigned to blue beads is a creation of archaeologists and has had little historic validity among African Americans in the past (e.g., Wheaton 1993:80).

The following essay evaluates the assumptions that blue is the most common bead color on slave sites and that these objects were symbolically laden artifacts for African Americans. Interpretation is based upon five interrelated facts: (1) between the 16th and 19th centuries Central and West African cultural groups used beads, in addition to other items, for adornment and as personal charms for protection from misfortune and illness; (2) these African-derived practices were in turn transplanted and reinterpreted by African Americans in the South; (3) enslaved African Americans participated in informal economies that provided limited access to material goods such as beads; (4) belief in the evil eye was present among slaves in the study region; and (5) the color blue, a recurring and abundantly documented motif in African-American folklore along the Sea Islands, is considered to be a potent form of spiritual protection. The role of blue beads considered in this essay is anthropologically relevant because these items provide insight concerning the African-American worldview they embodied. Hence, these artifacts and their related meanings offer an emic perspective regarding African-American material culture during the slavery era.

The results of archaeological data analysis are first presented followed by a brief overview of bead use in Africa. A discussion of how African Americans may have obtained beads is then offered. This study then considers the multiple functions of beads among slaves. This paper concludes with a discussion of the worldview and cultural processes illustrated by the use of blue beads by African Americans.

\section{Archaeological Data}

In plantation archaeology a systematic or synthetic study of beads from African-American sites has yet to be conducted. A data set based on the distribution of beads at African-American sites was 
therefore assembled to determine if blue was indeed the most common bead color at these sites. Artifact analysis was conducted at both national and regional levels. Data from North American sites illustrate general trends of bead use. To provide finer grained analytical resolution and a regional perspective, beads from South Carolina and Georgia sites are in turn considered in greater detail. Archaeological data incontrovertibly demonstrate blue beads are consistently represented more often than any other bead color on African-American sites.

Preliminary data were collected by placing a bead survey form in the spring 1994 issue of AfricanAmerican Archaeology (No. 10). The survey form listed frequency of beads found by color, probable date range, and context. Beads were recovered from rural and urban sites, and the contexts consisted of burials, middens, and structural features. Information provided in the survey responses was supplemented with published testing and excavation reports. The survey responses were from Alabama, California, Georgia, Kentucky, Louisiana, North Carolina, South Carolina, Tennessee, Virginia, Montserrat, and Barbados. These data are from a total of 51 temporal components and 26 sites. As illustrated in Table 1 , considerable variety exists within this sample. Blue beads comprise 27 percent of the total site sample $(n=1,676)$. Blue is the most prevalent bead color and blue beads are present in 63 percent of the components. No other color is as uniformly represented. The difference in the distribution of beads by color at these sites proved to be statistically significant $\left(X^{2}=1,462.29, d f=10\right.$, $p=<.001)$. The unidentified bead category was removed before calculating this statistic for glass beads. The assembled information clearly illustrates that although blue is not always the most prevalent bead color at each African-American site across the country, blue nevertheless is the most consistent bead color present at each African-American site. No other bead color is as uniformly represented in the national site sample.

To provide finer grained analytical resolution, a data set based on beads from a specific geographic region was assembled. Beads from African-American sites in South Carolina and Georgia were ex-
TABLE 1

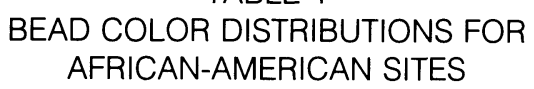

\begin{tabular}{|c|c|c|c|c|}
\hline \multirow[t]{2}{*}{ Bead Color } & \multicolumn{2}{|c|}{ Bead } & \multicolumn{2}{|c|}{ Components } \\
\hline & $\mathrm{N}$ & $\%$ & $\mathrm{~N}$ & $\%$ \\
\hline Blue & 448 & 26.73 & 32 & 62.75 \\
\hline Black & 64 & 3.82 & 6 & 11.76 \\
\hline Green & 50 & 2.98 & 5 & 9.80 \\
\hline Clear & 343 & 20.46 & 14 & 27.45 \\
\hline White & 139 & 8.29 & 16 & 31.37 \\
\hline Multicolor & 200 & 11.93 & 9 & 17.65 \\
\hline Red & 79 & 4.71 & 10 & 19.61 \\
\hline Purple/Pink & 17 & 1.01 & 3 & 5.88 \\
\hline Amber & 12 & 0.72 & 3 & 5.88 \\
\hline Yellow & 15 & 0.89 & 6 & 11.76 \\
\hline Brown & 232 & 13.84 & 4 & 7.84 \\
\hline Stone & 4 & 0.24 & 4 & 7.84 \\
\hline Shell & 11 & 0.66 & 4 & 7.84 \\
\hline Unidentified & 62 & 3.70 & 12 & 25.53 \\
\hline Total & 1,676 & 99.98 & & \\
\hline
\end{tabular}

Sources: Survey responses supplemented by Ascher and Fairbanks (1971); Smith (1975, 1977); Good (1976); Handler and Lange (1978); Drucker and Anthony (1979); Wheaton et al. (1983); Carnes (1984); Zierden et al. (1986); Gardner (1987); Watters (1987); Babson (1989); Shogren et al. (1989); Wayne and Dickinson (1990); Pogue and White (1991); Norrell and Meyer (1992); Praetzellis and Praetzellis (1992); Stine (1993); Heath (1994); Stine et al. (1994); O'Malley (1995); Steen (1995).

amined in greater depth due to the larger number of African-American sites that have been investigated in these states. The geographic setting of the majority of the study sites was the lower coastal plain and coastal areas in South Carolina. The level of investigation for the site sample was either intensive testing or excavation. Archaeological investigations that relied only on survey methods were not considered since survey methods usually result in low recovery rates for small artifacts. Data were obtained primarily from published books and compliance reports. Information concerning the geographic setting, site function, excavation methods, temporal periods, bead colors, bead types, counts, and authors' interpretations of the beads was tabulated. Frequency and color were the most consistently recorded attributes of analysis. Bead type and size were not always recorded or comparable. The 
TABLE 2

BEAD COLOR BY SITE FUNCTION ON AFRICAN-AMERICAN SITES IN SOUTH CAROLINA AND GEORGIA

\begin{tabular}{|c|c|c|c|c|c|c|c|c|}
\hline \multirow[t]{2}{*}{ Bead Color } & \multicolumn{2}{|c|}{ Domestic } & \multicolumn{2}{|c|}{ Kitchen } & \multicolumn{2}{|c|}{ General } & \multicolumn{2}{|c|}{ Total } \\
\hline & $\%$ & $(\mathrm{~N})$ & $\%$ & $(\mathrm{~N})$ & $\%$ & $(\mathrm{~N})$ & $\%$ & $(\mathrm{~N})$ \\
\hline Blue & 47.6 & (101) & 24.4 & (10) & 20.9 & (29) & 35.7 & (140) \\
\hline Black & 15.6 & (33) & 2.4 & (1) & 10.8 & (15) & 12.5 & (49) \\
\hline Green & 9.0 & (19) & 4.9 & (2) & 3.6 & (5) & 6.6 & (26) \\
\hline Clear & 6.6 & (14) & 12.2 & (5) & 2.2 & (3) & 5.6 & (22) \\
\hline White & 4.2 & (9) & 36.6 & (15) & 45.3 & (63) & 22.2 & (87) \\
\hline Multicolor & 3.8 & (8) & 7.3 & (3) & 7.2 & (10) & 5.4 & (21) \\
\hline Red & 2.8 & (6) & & & 2.9 & (4) & 2.6 & (10) \\
\hline Unidentified & 3.3 & (7) & 7.3 & (3) & 3.6 & (5) & 3.8 & (15) \\
\hline Purple/Pink & 2.8 & (6) & & & & & 1.5 & (6) \\
\hline Amber & 1.4 & (3) & 4.9 & (2) & & & 1.3 & (5) \\
\hline Yellow & 1.4 & (3) & & & & & 0.8 & (3) \\
\hline Stone & 0.9 & (2) & & & 0.7 & (1) & 0.8 & (3) \\
\hline Gray & 0.5 & (1) & & & & & 0.3 & (1) \\
\hline Gold & & & & & 0.7 & (1) & 0.3 & (1) \\
\hline Brown & & & & & 0.7 & (1) & 0.3 & (1) \\
\hline Shell & & & & & 1.4 & (2) & 0.5 & (2) \\
\hline Total & 99.9 & (212) & 100 & (41) & 100 & (139) & 100.2 & (392) \\
\hline
\end{tabular}

Sources: Rayfield Plantation (Ascher and Fairbanks 1971); 38BK160 (Drucker and Anthony 1979); 38CH109 (Carrillo 1980); 38BK75, 38BK76, and 38BK245 (Wheaton et al. 1983); Cannon Plantation (Otto 1984); 38CH322 (Brockington et al. 1985); 38 DR38 (Zierden et al. 1985); Midway Plantation (Smith 1986); 38BK202 (Zierden et al. 1986); 38BU805 (Trinkley 1986); 9CM172, 9CM183, and 9CM194 (Adams 1987); 38GE267 (Michie 1987); 38AB9 (Orser et al. 1987); 38 GE306 (Michie and Mills 1988); 38BU96 (Trinkley 1990); 38CH1081, 38CH1083, and 38CH1086 (Wayne and Dickinson 1990); 38GE410 (Weeks 1990); 38BU805 (Espenshade and Grunden 1991); 38BU966 and 38BU967 (Kennedy et al. 1991); 38BU1214 (Trinkley 1991); 38CH1100 and 38CH1101 (Wood 1991); 38CH1098 (Gardner 1992); 38CH1199/38CH1200 (Gardner and Poplin 1992); 38 RD397 (Groover 1992); 38BK1608 (Steen 1992); 38LU323 (Trinkley et al. 1992); 38GE377 (Adams 1993); 38BU880 (Kennedy et al. 1993); Bowers Housesite (Paonessa et al. 1993); 38CH127 (Trinkley 1993a); 38GE294, 38GE297, and 38GE340 (Trinkley 1993b); 38FL240 (Trinkley et al. 1993); 38CH812 and 38CH1214 (Wheaton 1993); 38BU791 (Eubanks et al. 1994); $38 B$ B890 (Garrow 1994); 38BU647 (Kennedy et al. 1994); 38BR522, 38BR619, and 38BR629 (Crass and Brooks 1995); 38 BK38 (unpublished).

bead data were placed in three broad temporal periods: the colonial period-18th century; the antebellum period-19th century, pre-Civil War; and the postbellum-modern period-post Civil War to 1950. Recovery locations and contexts were separated according to the categories of African-American residences - slave quarters, tenant and yeoman farms; plantation kitchens; and plantation complexes. The plantation complex category refers to excavations around the main house or excavations that did not firmly determine the specific functional context yet contained a large proportion of Colono Ware. It is assumed this distinctive ware indicates an African-American presence (Ferguson 1992).
The South Carolina and Georgia study sample is composed of 392 beads recovered from 50 sites that possessed 58 temporal components (Table 2). Within this site sample, beads were recovered at 42 sites, and blue beads were found at 34 sites representing 81 percent of the sites that contained beads. Glass is the primary material type but plastic, shell, and stone beads were also recovered. The sample contained a wide range of bead colors including red, green, yellow, pink, blue, gray, and white. There were also several polychrome beads-i.e., twotoned, striped, and floral-within the sample. The results clearly indicate blue is the predominant color of beads found on sites inhabited by African Amer- 
TABLE 3

BEAD COLOR BY TEMPORAL PERIOD ON AFRICAN-AMERICAN DOMESTIC SITES IN SOUTH CAROLINA AND GEORGIA

\begin{tabular}{|c|c|c|c|c|c|c|}
\hline \multirow{3}{*}{ Bead Color } & \multicolumn{6}{|c|}{ Period } \\
\hline & \multicolumn{2}{|c|}{ Colonial } & \multicolumn{2}{|c|}{ Antebellum } & \multicolumn{2}{|c|}{ Postbellum } \\
\hline & $\%$ & $(\mathrm{~N})$ & $\%$ & $(\mathrm{~N})$ & $\%$ & $(\mathrm{~N})$ \\
\hline Blue & 51.1 & (24) & 52.2 & (60) & 34.0 & (17) \\
\hline Black & 2.1 & (1) & 15.7 & (18) & 28.0 & (14) \\
\hline Green & 6.4 & (3) & 7.0 & $(8)$ & 16.0 & (8) \\
\hline Clear & 6.4 & (3) & 8.7 & (10) & 2.0 & (1) \\
\hline White & 4.3 & (2) & 2.6 & (3) & 8.0 & (4) \\
\hline Multicolor & 12.8 & (6) & & & 4.0 & (2) \\
\hline Red & 2.1 & (1) & 2.6 & (3) & 4.0 & (2) \\
\hline Unidentified & 12.8 & (6) & 0.9 & (1) & & \\
\hline Purple/Pink & & & 3.5 & (4) & 4.0 & (2) \\
\hline Amber & & & 2.6 & (3) & & \\
\hline Yellow & & & 2.6 & (3) & & \\
\hline Stone & 2.1 & (1) & 0.9 & (1) & & \\
\hline Gray & & & 0.9 & (1) & & \\
\hline Total & 100.1 & (47) & 100.2 & (115) & 100.0 & (50) \\
\hline
\end{tabular}

Sources: Rayfield Plantation (Ascher and Fairbanks 1971); 38BK160 (Drucker and Anthony 1979); 38BK75, 38BK76, and 38BK245 (Wheaton et al. 1983); Cannon Plantation (Otto 1984); 38CH322 (Brockington et al. 1985); 38BK202 (Zierden et al. 1986); 38BU805 (Trinkley 1986); 9CM172, 9CM183, and 9CM194 (Adams 1987); 38GE267 (Michie 1987); 38AB9 (Orser et al. 1987); $38 \mathrm{GE306}$ (Michie and Mills 1988); 38BU96 (Trinkley 1990); 38CH1081, 38CH1083, and 38CH1086 (Wayne and Dickinson 1990); 38GE410 (Weeks 1990); 38BU805 (Espenshade and Grunden 1991); 38BU966 and 38BU967 (Kennedy et al. 1991); 38BU1214 (Trinkley 1991); 38CH1 100 and 38CH1101 (Wood 1991); 38BK1608 (Steen 1992); 38GE377 (Adams 1993); 38BU880 (Kennedy et al. 1993); Bowers Housesite (Paonessa et al. 1993); 38GE297 and 38GE340 (Trinkley 1993b); 38FL240 (Trinkley et al. 1993); 38BU791 (Eubanks et al. 1994); 38BU890 (Garrow 1994); 38BU647 (Kennedy et al. 1994); 38BR522, 38BR619, and 38BR629 (Crass and Brooks 1995); 38BK38 (unpublished).

icans in the South Carolina and Georgia region. Blue beads comprise 36 percent $(n=140)$ of the total sample. For the analysis category of location, blue beads comprise 48 percent of the sample from African-American residences, 24 percent of the sample from plantation kitchens, and 21 percent of the sample from general plantation contexts (Table 2). A chi-square test of association indicates the difference in the distribution of blue beads between African-American domestic components and other plantation areas is significant $\left(X^{2}=28.7784998, d f\right.$ $=1, p=<0.01)$. This comparison indicates while blue beads were typically lost in a variety of locations on plantations, these beads were predominantly lost or intentionally discarded in and around African-American residences.

Consideration of African-American sites, con- sisting of slave, tenant, and yeoman domestic components, by temporal period, indicates blue beads were much more prevalent during the colonial and antebellum periods than after the Civil War (Table 3 ). Blue beads represent 51 percent of the sample during the colonial period and 52 percent during the antebellum period. During the postbellum period both blue (34\%) and black $(28 \%)$ are the predominant bead colors. A chi-square test demonstrated the difference in the distribution of blue beads between the colonial-antebellum and postbellum periods is statistically significant $\left(X^{2}=4.88138515, d f\right.$ $=1, p=<0.05$ ).

Analysis results firmly demonstrate that blue beads were deposited most often in African-American domestic areas, particularly during the colonial and antebellum periods in South Carolina and Geor- 
gia. If the distribution of blue beads was only a result of availability and not cultural preference, blue beads should have been found equally in all areas of the plantation.

\section{West and Central African Antecedents}

In order to achieve an enhanced understanding of bead use among African Americans in the South, the African antecedents of this practice must first be considered. Among the estimated 10 million Africans brought to the New World between the 16th and mid-19th centuries (Blassingame 1974:3), approximately 40 percent originated in Kongo and Angola (Thompson 1993:56). These areas of Africa included many different tribes such as the Ibo, Ewe, Biafada, Bakongo, Wolof, Bambara, Ibibio, Serer, and Arada (Blassingame 1974:2). Since AfricanAmerican slaves originated from such a wide range of cultural groups, it is difficult to associate specific African cultural groups with specific regions in the South. Also, slave traders and holders were aware of ethnic differences (Littlefield 1981:115-173) and therefore often intentionally broke up ethnic groups and families (Genovese 1974). Consequently, specific, as opposed to regional, origins for individual plantation inhabitants are very difficult, if not impossible to reconstruct.

Many South Carolina slaves, a regional focus of this study, originated from the Kongo-Angola region and the rice growing areas of Gambia and the Windward coast. A study of slaves imported to Charleston from 1733 to 1807 records six major source areas for slaves: Senegambia (19.7\%); the Windward Coast (23.3\%); Gold Coast (13.4\%); Whydah-Behhin-Calabar area (3.7\%); Congo (16.9\%); and Angola (23\%) (Pollitzer 1975:268; cf. Littlefield 1981:109-114; Creel 1988:16-44; Ferguson 1992:61; Kernan 1993:30; Thompson 1993: 56). Africans from Gambia were desired by South Carolina planters because they already had specialized knowledge needed for the successful cultivation of rice and indigo, which were important regional cash crops (Creel 1988:34-36; Ferguson 1992:61).

Due to the demographic realities of the African slave trade, discussed above, African-American culture in the South during the era of slavery should therefore be regarded as a fusion of African-inspired cultural forms and practices. Hence, it is expected that bead use among enslaved AfricanAmericans represents a pan-cultural phenomenon derived from African origins. It is not only difficult but counterproductive to attempt to identify direct, one-to-one correspondences between artifact patterning and artifact types at specific plantation sites and specific ethnic groups in Africa. However, it is not unreasonable to anticipate that broadly based practices and beliefs associated with beads and personal ornamentation, in addition to other aspects of the material domain, both survived the middle passage and were eventually transformed into new cultural traits by enslaved African Americans in the South.

Long before the arrival of Europeans, beads were an important aspect of West and Central African material culture. Beads had many religious and secular uses in Africa. Lois Dubin (1987:122), who has collected and studied beads from around the world, notes that "beads are central to the lives of all Africans" and have a wide variety of functions. Historic travelers to West Africa recorded that people used beads to adorn their body, as jewelry, to adorn ceremonial costumes, and to decorate everyday clothes. Today, and in the past, West Africans wear beads in their hair, on clothing, and as necklaces, bracelets, waistbands, and anklets. Beads were a form of personal adornment and perhaps more importantly, they conveyed social meaning and denoted information concerning wealth, age grade, marital status, artistic attitudes, and political, religious, and cultural affiliation. Beads were also important trade items often used as currency. These items were also associated with myths, with ceremonies such as rites of passage, and with religious cults, and were made into sculptural beadwork and worn as amulets and charms (Rattray 1923:147, 187, 1927:22, 46, 62, 66, 171; Ellis 1964:232, 235 , 237, 240; Farrow 1969:47; MacDonald 1969:5861; Courlander 1975:120-123; Fisher 1984:67106; de Marees 1987; Dubin 1987:119-151). Furthermore, different regions or cultural groups had particular preferences for certain bead types and 
colors (Erikson 1969:59; de Marees 1987:56; Nourisson 1992:29). In contemporary West Africa, beads manufactured in the 19th century are often curated and highly valued (DeCorse 1989:44; Steiner 1990:59). For example, although Côte d'Ivoire women of West Africa wear modern European-style jewelry manufactured from gold, silver, and plastic, glass trade beads are nevertheless still valued and purchased for their spiritual potency (Steiner 1990:59).

The manner in which West and Central Africans incorporated beads into charms, amulets, and fetishes is particularly relevant to this study. Charms, considered to have spiritual power, are used to insure success in all aspects of life, including journeys, hunting, farming, and romance, as well as to ward off evil, sickness, and misfortune, and to gain material goods (Kingsley 1897:448; Nassau 1904: 78, 83; Lowie 1924:269-270; Wallis 1939:33-34; Farrow 1969:122-124). Some charms are used to avert witchcraft, particularly as manifested through illness and misfortune. Amulets therefore have an important function in health care among West and Central African groups. For example, among various West African groups, where infant mortality is high, it is thought that mothers and children particularly require the protection provided by charms and amulets (Rattray 1927:22; Ellis 1964:232; Janzen 1982:55-56; de Marees 1987:25, 75). Farrow (1969:84) notes that among the Yoruba Abiku cult, to prevent harm from the vengeful spirits of children that died in infancy, "iron rings, waist belts, anklets, and wristlets of beads and other charms are put upon young children from their earliest days." A string tied around the waist of a child is also a widespread West African charm (Milligan 1912: 220). American writer Era Bell Thompson (1954: 26) observed a Liberian infant encircled by a string of blue beads (cf. DeCorse [1997]). This amulet is worn throughout childhood for good health. In Kongo terms, this practice keeps the child's soul round, or rich, with life's possibilities. A mother would "fashion a small round disk from wood or a seed, perforate it, and attach it to a string to hang over his heart or tie around her neck, waist, or ankle. This would become a guide and charm to the child's soul, guarding its round boundaries, charting the child's safe circuit to maturity and old age" (Thompson 1993:57).

Charms were expressed verbally, through ceremony or as material objects (Milligan 1912:220; Farrow 1969:121). Amulets, charms, and fetishes are any material object that is thought to contain spiritual power (Lowie 1924:268-270; Wallis 1939:33-34; Hoebel 1966:487). Many items are used for charms including beads, animal bones or teeth, stones, iron, broken pottery, feathers, bits of skin, leaves, hair, and fingernails (Nassau 1904:76, 84-85; Puckett 1975:172, 217-218). There are principally two types of charms, consisting of personal and household amulets (Burton 1864:361; Baudin 1885:83; Ellis 1894:118; Parrinder 1957:114-115, 1961:160-161; Farrow 1969:123; Awolalu 1979: 79). Personal amulets are worn around the neck, arm, wrist, or ankle. These objects protect the wearer. Household amulets are placed on the house or on household property to protect the actual structure, its contents, and residents (Parrinder 1957: 114-115, 1961:160-161; Nassau 1969:85; Ellis 1970:92).

Beads were, and still are, typically used for making amulets and charms among many African cultures (Baudin 1885:83; Rattray 1927:22; Nassau 1969:82). However, within some regions, such as southern Togo, beads are rarely used in charms (Nourisson 1992:32). Among the people of the Gold Coast, bead charms were often worn by pregnant women on their wrists, ankles, and neck to avert harm (Ellis 1964:232). Among the Ewe, a Popo bead and human tooth worn around the neck prevented sickness (Ellis 1970:93). In 17th-century Guinea, the traveler de Marees (1987) recorded that shirts fashioned like nets were worn by small children. The children's parents would:

drape the Net extensively with their Fetissos, such as little golden crosses, tie strings of beads around the children's hands, feet and neck, and fill their hair with little shells, which they greatly esteem; for they say that as long as the young child is draped with this Net, the Devil cannot catch the child or carry it away; but without it would be carried away by the Devil. They highly esteem the Fetisso of the Beads which they hang around the neck of the little child and they consider it protection against vomiting, falling, bleeding, harmful animals, unhealthiness, and for sleeping well (de Marees 1987:25). 
In contemporary Guinea, this custom persists and parents still adorn and protect their infants with various amulets, beads, cowrie shells, and bangles (de Marees 1987:25).

The above review illustrates that in West Africa beads were often used in amulets for protection from harm and illness. The archaeological data gathered for this study indicate blue beads are associated with African-American sites. To understand the role of these artifacts in the lives of African Americans it is, in turn, necessary to consider the meaning and uses of blue beads in West Africa.

European visitors to West Africa between the 15th and 19th centuries observed that certain blue beads were highly valued. The most well-known bead is the aggri or akori bead, which was possibly blue (Fage 1962; Landewijk 1970; Davison et al. 1971; Kalous 1979). Magical and mythical qualities were associated with this bead. Aggri beads were incorporated into jewelry, but they were also used in ritual and placed in burials. Among the Ashanti aggri beads were often placed in containers during offerings and divination (Parrinder 1961:67). Along the Gold Coast this bead was worth its weight in gold, and a person's wealth could be determined by the number of aggri beads they owned (MacDonald 1969:58-61).

Upon initial consideration the aggri appears to be an appropriate example of blue bead use in West Africa that could demonstrate continuity with African-American practices. However, as a caveat it should be emphasized that West and Central African groups exhibited tremendous cultural variation. DeCorse ([1997]) also emphasizes that beads had numerous uses and meanings among cultural groups involved in the Atlantic slave trade, and likewise slaves may have had a range of uses and meanings for blue beads. In summary, this section has attempted to illustrate that beads in West and Central Africa were important social, economic, and religious items that were used for a wide range of purposes.

\section{Bead Sources and Availability of Goods}

Archaeological data indicate the distribution of beads at South Carolina and Georgia sites is sta- tistically significant in terms of differences in color, context, and time periods. This section considers the crucial element of acquisition-or how enslaved African Americans, tenants, and freed persons may have obtained beads. Archaeological interpretation of personal artifacts such as beads is usually based on the assumption that they were bought by planters for African Americans, were hand-me-downs from the planter family, or were stolen (e.g., Kelso 1984: 190, 201). A few reports indicate that some personal items may have been curated heirlooms or were produced by slaves for their own use (e.g., Drucker and Anthony 1979; Wheaton et al. 1983; Otto 1984: 73, 174-175; Zierden et al. 1986). If slaves indeed had little or no influence in the items they used in daily life, then the distribution of beads identified in this study may merely reflect the tastes or economies of planters and overseers. If slaves were able to make decisions concerning their material life, then bead color preferences should be viewed as an aspect of African-American consumerism within the informal slave economy.

Conversely, beads from African-American sites may merely reflect availability and manufacturing trends rather than slave or planter choices or cultural preferences. In order to explore these issues, the color distributions of glass beads that were produced, sold, and traded between the 17th and 19th centuries were investigated. This proved a daunting task, since published reports detailing production types and numbers are not readily available. $\mathrm{Nu}$ merous glassmakers produced beads throughout Europe, Asia, and the Middle East and most kept information about processes, amounts, and other manufacturing arts secret (e.g., Moore 1924:48-50; Robertson 1969:38; Kidd 1970; Smith and Good 1982:12-15; Harris 1984; DeCorse 1989:41-44). Two published bead catalogs suggest that manufacturers offered more varieties of blues, bluegreens, and greens than other colors (Karklins 1985: 12,43 ). This trend could be the result of consumers purchasing more shades of blue and green, or merely bead manufacturing technology. In discussing glass production, Jones and Sullivan (1989:14) state that "cobalt is one of the strongest colorants available to glass manufacturers." Nonetheless, if bead consumers refused to purchase, trade, or use 
blue beads, it is doubtful that so many varieties would have been available in bead catalogs.

Concerning bead sources, colonial merchants and planters often participated in both the African and Indian trade. Deeply involved in the mercantile system, merchants and planters ordered goods on credit from factors in colonial ports such as Charleston, or directly from factors in London (Rawley 1981; Stine 1990; Braund 1993). During the 17th century, Amsterdam was the " . . . great entrepôt for western Europe. To it came the products needed in the slave trade: cloths from many nations, beads, copper, iron, brandy, and tobacco, and numerous other commodities. Slave ships from foreign nations, notably England, often put into Amsterdam to acquire wares for the African trade"' (Rawley 1981: 81). Traders and planters often purchased goods from the same London merchants (Stine 1990:27). Late 18th-century Bristol slave trader James Rogers mentions his captain buying trade goods at "the bead store" in London. There he "found beads plentiful, but he had not determined the price for cowries"' (Rawley 1981:186).

Bristol slave ships carried numerous slaves to Virginia and the Carolinas. Some local traders waited and purchased leftover goods from African slave dealers in Virginia ports. Travelers and traders, in the words of John Lawson, "came often to a good Market, at the Return of the Guinea-Ships for Negro's, and the Remnant of their Stores, which is very commodious for the Indian-Trade' (Lefler 1967:94). Their merchandise likely included beads. This information suggests that a variety of goods were available in the colonies for the Indian trade as well as for resale to plantation owners, local storekeepers, and the general population.

Lists of trade goods, account books, and published histories of some of the great trading houses were consulted to gain a sense of the amounts and types of beads shipped to North America (e.g., Crane 1928; Coker 1976; Coker and Watson 1986; Wright 1986; Weisman 1989; Stine 1990; Merrell 1991; Braund 1993). Unfortunately, most trade lists merely record the price of strings of beads in number or weight of deerskins without mentioning color (e.g., Crane 1928:331-332). Occasionally a record with a little more detail is encountered, such as a listing that enumerated "5 strings barley seeds, 5 strings common beads, 10 strings white enameled beads"' (Weisman 1989:67, Table 4).

\section{Consumer Choice}

The above discussion illustrates that primary and secondary information concerning the range and types of beads produced in the Old World and shipped to North America is not abundantly available. However, a substantial amount of information regarding the types of items preferred by traders and merchants, and perhaps more importantly, the influence exerted by consumers, has been recorded since the 17 th century. The influence of local demand on the types of goods offered by European traders is illustrated in Senegal, West Africa (Opper and Opper 1989:5-6). In 1678 French voyager Jean Barbot noted that specific beads were preferred by certain African buyers. Some trade goods were purchased by inhabitants and remade into items that conformed to local taste (Opper and Opper 1989:7). West Africans in Senegal were willing to pay more for certain types of beads and often refused to purchase goods made in unpopular colors or shapes (Opper and Opper 1989:5-8).

In North America there are numerous examples of the effect of consumer choice on the types and varieties of colonial and antebellum trade goods, particularly for Native American contexts. Traders and factors often complained of kettles that were too large or of receiving shipments of beads and blankets that were the wrong colors-items that Native Americans, in turn, adamantly refused to purchase (e.g., Peake 1954:70; Stine 1990; Braund 1993: 121). William Byrd (in Tingling 1977:63-64) wrote to merchants Perry and Lane in 1686 complaining, "Your duffeilds this year proved indifferent onely narrow \& some too light a blew . . . beads you sent me [were] large white instead of small. I can by no means put them of, pray (if it's not too late) send me none but small white this year.' 'Braund (1993: 121) writes that "Creek spokesmen were very specific about what they needed and wanted in exchange for their deerskins." Thus, among Native Americans during the colonial period there existed a clear pattern of consumer choice that affected the 
quality, range, and types of goods that were traded, including beads. For example, in a recent study of Plains Indian bead use and ethnicity, researchers discovered that many tribal groups used similar colors and types of beads. The selection of design elements, however, was directly related to the ethnicity of the maker and the time period of manufacture (Logan and Schmittou 1995). Archaeological data likewise substantiate this interpretation. Beads from trading posts across North America illustrate the extent of variation in consumer demand that existed among Native Americans. Consequently, the distribution of beads recovered at individual posts was undoubtedly influenced by the cultural preferences of the native groups that were trading at specific posts (DeVore 1992:61). For example, 72 percent of the beads recovered from Fort Michilimackinac, Michigan, for contexts dating between 1714 and 1781, were white (Stone 1974). At Fort Vancouver, British Columbia, for contexts dating between 1829 and 1860,57 percent of the beads found in the fort and 74 percent of the beads from the Indian trade store were white (Ross 1990). The most prevalent bead color from Fort Union, North Dakota, occupied between 1829 and 1865 , was blue, comprising 43 percent of the bead assemblage (DeVore 1992).

Archaeological studies of Native American groups in the Eastern Woodlands indicate a similar pattern. The same bead types were traded throughout the area, but Native American groups firmly preferred specific colors and bead types (Smith 1983:151). For example, in the Northeast, red beads predominate at archaeological sites (Hamell 1983; Kenyon and Kenyon 1983:69; Smith 1983:151). Conversely, in the Chesapeake, blue beads and blue and white striped glass beads are by far the most prevalent on 17th-century Native American and trader-planter sites (Miller et al. 1983:133, Table 3). In Jamestown, between 1607 and 1608, Captain John Smith traded 4 lb. of beads for 600 bu. of corn, since he had convinced local leaders that blue beads were used by only the most high-status chiefs (Miller et al. 1983:127). Fourteen years and a rebellion later, " 20,000 blue beads were paid for some mats,' indicating blue beads were no longer viewed as scarce, high-status items (Miller et al. 1983:127). As the period of intense Indian trade declined, so too did the number of blue and other beads in regional sites (Miller et al. 1983:130-132).

In a study that compared 19th- and 20th-century Upper Creek towns in Alabama and Georgia to Creek towns in Oklahoma, Good discovered a contrasting pattern in bead use. In Oklahoma Creek artifact assemblages "anything other than blue and 'white' faceted beads is in limited quantities; and of the faceted beads, there are always a greater number of blue ones." Varieties of blue beads were also the most prevalent in the Alabama and Georgia study sites (Good 1983:160, 162). Seminole sites dating to the 1830s also often contain large proportions of blue beads (Piper and Piper 1982; Piper et al. 1982; Weisman 1989:69-76).

The North Carolina Occaneechi, who were middlepersons in the southern piedmont trade between 1680 and 1710 (Stine 1990), did not prefer blue or even red beads, but white (Carnes 1987:151). Sissipahaw villagers between 1660 and 1680 preferred blue and white seed beads (Carnes 1987:151; Ward and Davis 1993:109, 141). In the village of Upper Saratown along the Dan River, the Sara also decorated their clothes with sewn white and blue seed beads, and occasionally wore necklaces and bracelets of large white, blue, and blue and white striped beads (Ward and Davis 1993:423-428).

Although blue was a common bead color used by Native Americans and Euroamericans, it is not the most prevalent color at all non-African-American sites. Native Americans displayed pronounced variation in bead use and preferences, especially during periods of culture contact and change. If Native Americans and Euroamericans could significantly influence the types of beads obtained from traders, then it is not unreasonable to infer that the distribution of beads characteristic of African-American sites is likewise quite possibly the result of cultural preferences and consumer choice rather than mere market availability. Consideration of the informal slave economy reinforces this interpretation.

\section{The Informal Slave Economy}

The idea that enslaved peoples had some control over their symbolic and material world has been 
discussed in recent archaeological studies (Singleton 1991; Orser 1994). However, the notion of slaves as consumers appears contradictory. Archaeologists typically think about enslaved African Americans as producers, but seldom as consumers. One can infer that if slaves were also consumers, they may have influenced the types of goods made available for sale. In order to resolve this issue, archaeologists must first determine if slaves exercised decision-making in the acquisition of material goods such as beads. What were their opportunities to purchase them, and did they have the means to do so?

Although planters provisioned slaves, the quality and quantity of goods differed by individual inclination and wealth. On many plantations slaves were expected to contribute towards their own provisioning-from garden plots and wild foodstuffs (Berlin and Morgan 1990:3-4; McDonald 1990:187; Gasper 1991:134-135). As a consequence of this practice, an informal barter economy quickly developed in which slaves exchanged surpluses with each other, with plantation owners, and with local storekeepers (Berlin and Morgan 1990:12). In many regions slaves, and later tenants, excelled at poultry production, selling eggs and fowls both on and off the plantation (Schlotterbeck 1990:170, 189; Pulsipher 1991:150-155). Sunday markets were also commonplace, where slaves sold poultry, garden produce, fish, and handcrafts (Mintz and Hall 1960; Price 1966; Berlin and Morgan 1990:9-11, 13; Pulsipher 1990, 1991; Schlotterbeck 1990:173; 189). In the early 19th century, South Carolina slaves often personally sold goods at public markets (Campbell 1990:147).

Many slaves also labored extra hours during official rest periods, such as holidays, during the evening, on Saturday afternoons, and Sundays. They worked in their gardens or at their crafts, but some also toiled additional hours both on their own and on the planter's cash crops. Through these efforts they earned cash, either by direct wages or selling bales of cotton, cords of lumber, or other commodities. Some planters arranged for slaves to work for other planters as skilled laborers. In some cases, slaves received a portion of the wages. Over time occasional work privileges were viewed as entitlements (Berlin and Morgan 1990:4; Campbell 1990:134, 141; McDonald 1990:187).

Several laws were passed in various regions to stop or control these practices but had little success (Berlin and Morgan 1990:10; Campbell 1990: 143-144; Schlotterbeck 1990:171). Slaves sold their legal-and illegal-goods to yeomen, to local storekeepers, to itinerant peddlers, and to planters (Berlin and Morgan 1990:12; Campbell 1990:140; McDonald 1990:195-197; Schlotterbeck 1990:173, 175, 190-191). During the later antebellum period some planters regained more control over their slaves' purchasing activities by issuing credit instead of cash. Planters also became factors for their slaves' goods (Campbell 1990:151). This modification of the informal economy in turn reduced direct access to markets.

Slaves rarely accumulated large sums of cash or credit. They could only marginally participate in personal enterprises outside the heavy demands of plantation labor. For example, Guignard Plantation slaves in upcountry South Carolina made about three dollars a year between 1802 and 1804. Campbell (1990:135) estimates the typical field hand earned between $\$ 3$ and $\$ 8$ annually. At the Gay Plantation in Louisiana, slaves in 1844 earned between $\$ 1$ and $\$ 82$. Between 1858 and 1859 slaves at Tureaud's Plantation earned between $\$ 1$ and \$170 (McDonald 1990:191, 199).

Slaves purchased a great variety of items, especially "tobacco, alcohol, cloth, clothing, bowls, pots, and other utensils" as well as jewelry, watches, and other personal goods (Berlin and Morgan 1990:13; McDonald 1990:135-136, 200-201; Schlotterbeck 1990:177). Larger commodities such as stock animals and furniture were also purchased, but less frequently (Berlin and Morgan 1990:13). When comparing Georgia and South Carolina plantation task labor systems, Joseph (1987) discovered a generalized pattern of slave purchases. The three general categories of purchased goods were improved subsistence items, high-status objects, and luxury consumables. He states, "Items which reflect personal/individual status, such as finer quality clothing, beads, elaborate buttons, eyeglasses, . . . or [artifacts which demonstrate] the success of entire households and families, such as wagon and 
buggies, decorative ceramics, mirrors, more elaborate furniture, and perhaps window glass, would be another means of expressing financial accomplishments through a material medium' (Joseph 1987: 5). These items may have been multifunctional, communicating more than economic information within slave society.

Historical studies of the informal slave economy do not list the entire range of items that were purchased or traded. They do, however, mention many primary sources that list these goods. For example, Negro Account Books maintained by merchants and plantation records offer a wealth of information for future research. Besides urban merchant houses and stores, colonists could purchase goods from local stores. These stores became more plentiful in the antebellum period.

In the postbellum period, local stores gained an important role in the economic system, replacing many of the large urban factors (Stine 1989). Some of the larger landowners also operated commissaries for laborers (Campbell 1990:147). The store ledgers for Oakley Plantation, Louisiana 'demonstrate that African-American tenants bought 'lace,' 'trim,' 'beads,' and 'buttons' to ornament their clothing', (Wilkie 1994:4; cf. Bell 1994:9). Likewise, an 1871 account book lists items purchased by an African-American servant from a Pike County, Georgia, store. She purchased a number of items on credit, including "one string of beads" worth $\$ 0.25$ (Fincher 1871).

Extant information therefore underscores the fact that many enslaved individuals participated in local, informal economies. During the last four centuries, people of African descent have therefore had access, albeit differential and circumscribed, to material goods. These men and women often maintained exchange relations with individuals on other plantations, as well as traders, peddlers, and storekeepers. It is not far-fetched to consider they may have exercised influence on the varieties of items sold and bartered, such as beads. Since people of African descent were able to pick and choose some of the things in their lives-certain material items like beads, other objects for personal adornment, and perishable or curated luxury goods - then it follows that slaves could also influence the types and varieties of goods stocked by merchants. Also, due to the autonomy represented by purchasing decisions, the personal artifacts encountered at slave sites may possess social and symbolic significance not usually recognized by archaeologists.

\section{Beads and African Americans in the South}

African-American culture developed and was transformed from West and Central African antecedents within the rural South, and beads illustrate one aspect of this historical process. Beads and their related meanings offer an emic understanding of rural African-American culture. In order to explore the role of beads among slaves, African-American belief systems must first be considered. While many slaves embraced Christianity and Islam, the forms of worship, organization of churches, tenets, and symbolic systems were often translated into a specifically African-American worldview (Herskovits 1962:207-260; Thompson 1993:74-95).

An appreciable degree of consistency existed with the rural, African-American worldview. This level of consistency suggests that the development of African-American culture from West and Central African antecedents and influences from European and Native American elements was a process characterized by selection and amplification (Herskovits 1962). This same cultural process has been documented by Joyner (1984:14) concerning the way a distinctive form of Christianity emerged from diverse West African belief systems and European influences among African Americans along the South Carolina and Georgia coast. Ferguson (1992) has likewise explored the fusion of cultural forms within African-American material culture during the colonial period. Thompson has also examined how this process is expressed in African-American art (Thompson 1993).

African and rural African-American belief systems were characterized by an animistic orientation in which the world was inhabited by both benign and malign spirits (Folklore Project [1930s]; Works Progress Administration [WPA] 1974[1940]; Puckett 1975; Joyner 1984). Individuals could both benefit and suffer from the whims of these forces, and 
conjurers were seen as powerful people who could control the supernatural. Illness and misfortune were typically explained through the actions of malevolent spirits.

Ex-slave interviews, compiled during the 1930s by the Works Progress Administration, convincingly demonstrate the persistence of West and Central African inspired animism in the South. The interviews were conducted among rural African Americans in a number of southern states. Although researchers using these collections have to be aware of the cultural context and biases in the oral history data, certain common themes emerge from these sources. As illustrated in the interviews, concern with good and bad spiritual forces was a central element in the rural African-American worldview. The mediator between the human and spiritual world was the minister and the conjurer. Besides prayer, one of the most efficient means for influencing the spiritual world was through the use of charms and amulets obtained from conjurers (WPA 1974[1940]:7, 20-21, 92, 124-125). The role of these individuals figured prominently in the culture of rural African Americans in the South. Blassingame (1974:45) notes, "Often the most powerful and significant individual on the plantation was the conjurer.' For example, in 1822, Gullah Jack drew some of his charisma as a leading rebellion figure for Lowcountry slaves from his use of powerful charms (Herskovits 1962:138).

Like their West and Central African predecessors, conjurers claimed they could influence all aspects of life, such as causing and preventing sickness and death and influencing romance and success. Healers also had extensive knowledge of the medicinal qualities of roots and herbs which were used to cure the sick. Reliance upon conjurers, their spiritual knowledge, and the charms they manufactured extended to all practical affairs of life within southern African-American culture. Charms and amulets were manufactured from a wide range of materials, represented by bluestone, blue glass, lodestone, red pepper, graveyard dirt, horseshoes, red flannel, hairpins, copper, silver, human hair and nails, nutmeg, buckeyes, beads, finger rings, wrist or ankle bands of various materials, and perforated coins (Botkin 1966:630-632; WPA 1974[1940]:74; Puckett 1975:235, 237, 240-241).

Personal charms in the South were typically worn on the neck, finger, wrist, waist, or ankle, tied or sewn to garments, and carried in the pockets, shoes, or hats (WPA 1974[1940]; Puckett 1975). Household charms were also distributed about the house, under or around the doorstep, placed under the bed or pillow, placed on a gatesill or doorsill, or over the door (Botkin 1966; WPA 1974[1940]). Personal charms, as noted in the ex-slave narratives, were used to prevent illness, ward away evil, and bring good luck in all aspects of life. Examples of personal charms consist of metal wire, heavy cord, or a leather strap worn on the ankle, wrist, or neck (WPA 1974[1940]:20-21; Rawick 1972a:235; Puckett 1975:314), nutmeg worn on a string around the neck to cure headaches (Rawick 1972b:244 245), and a silver coin worn around the ankle, neck, or in the shoe (WPA 1974[1940]:92, 125; Rawick 1972b:245, 1972c:31; Puckett 1975:288, 314; Escott 1979:109). In recent years archaeological examples of personal charms have been identified at numerous African-American sites (e.g., Adams 1987; McKee 1992; Patten 1992; Samford 1994; Young 1994; Singleton and Bograd 1995:23; Wilkie 1995; Russell 1996). Examples of likely house charms have likewise been documented at the Eno Quarter and Stagville Plantation, both near Durham, North Carolina, and at Prestwould Plantation in Mecklenburg County, Virginia (Samford 1996: 107-109).

The above information suggests that charms were a fundamental element of African-American material culture and belief systems. For example, Liza, a former slave from Harris Neck, Georgia, remembered that "most of the folks carry something for protection', (WPA 1974[1940]:125). Further, given their significance in West Africa, beads were probably a typical item used for charms in the South. African-American slaves, like their African predecessors, wore beads in jewelry or affixed to clothing. Although the role of beads among African Americans in the South was poorly documented, a few observations were recorded in the Caribbean. Griffin Hughes, a Caribbean planter, remarked in 
1750 that his slaves adorned their bodies with beads, but he did not offer an explanation for their purpose (Handler and Lange 1978:147; Karklins and Barka 1989:75). Europeans in Barbados and Jamaica also observed plant material, such as seeds, that were used for beads (Handler and Lange 1978:147). Eighteenth-, 19th-, and 20th-century engravings, portraits, and photographs depict African Americans adorned with beads. Beads have likewise been worn by African-American women, and some men, since the colonial period, and are still worn today. Illustrations may be found in Hughes and Meltzer (1968), Wesley (1968), Johnson and Dunn (1986), Welty (1989), Gasper (1991: 134-135), Singleton (1991:163), and White (1991: 102).

Ex-slaves in Georgia during the 1930s recalled that beads were worn for adornment (Rawick 1972c:217, 312, 1972d:71). Callie Elder, an exslave from Athens, Georgia, stated that "them blue and white beads what the grown woman wore was just to look pretty. They never meant nothing else', (in Rawick 1972c:312). The response provided by Callie Elder is interesting, since it implies that the interviewer thought blue and white beads had symbolic meaning. As Callie Elder noted in the 1930s, beads were often used for adornment. However, it is clear from ethnographic information that beads were more than mere ornaments in Africa. The role of beads as socially meaningful objects probably continued in the South, particularly among African Americans along coastal South Carolina and Georgia. This inference is supported by several examples which suggest that bead charms were often used by African Americans to avert misfortune and illness. Beads were also used during prayer by Muslim and Catholic African Americans.

Botkin (1966:630), a folklorist, recorded that beads were worn as charms in the South. Further, blue beads on African-American sites have been interpreted to be indicative of the evil eye belief (Adams 1987). Blue beads are considered to be particularly effective in warding away the evil eye in many cultures (Maloney 1976). The persistence of the evil eye belief in the study region is confirmed by the presence of practicing Muslim slaves, his- torical references to the evil eye, and archaeological evidence.

Ex-slave narratives collected during the Depression contain several direct references to Muslim religious practices (WPA 1974[1940]:76), including the use of prayer beads by Muslim African Americans. A former slave recalled that people would "pray on duh bead" (WPA 1974[1940]:166) and that "duh beads is on a long string. Belali he pull bead"' as he prayed (WPA 1974[1940]:161). Former slave Charles Ball also spoke of Muslim practices on the plantation where he resided. Ball recalled that one slave prayed five times a day to the east (Frazier 1930:202). The presence of Muslim religious practices in the Southeast may have included the use of blue beads to ward away the evil eye. Christian tradition is also another source for the evil eye concept. Both the books of Proverbs and Ecclesiastes contain references to the evil eye (Dundes 1981:41-43).

Laura Towne, a reconstruction-era schoolteacher on St. Helena Island, South Carolina, recorded in her diary that the Gullah "believe in the evil eye, and also in the power of a good eye for healing", (Creel 1988:315). Likewise, C. R. Tredman, a writer for the WPA Folklore Project in South Carolina, recorded from an informant in the 1930s that, among African-American residents of Edisto Island,

\footnotetext{
some would rather encounter the devil himself than the [witches] known as hags, for if one of them should cast her eye in their direction bad luck would overtake them. Some believe that a hag can bewitch a person by merely looking at them. This is known as the "evil eye"' and is very much feared (Folklore Project [1930s]:1655, D-4-27A:2).
}

Puckett (1975:188) also recorded that African Americans used charms and amulets to avert the Judas eye, another name for the evil eye. Beads, then, were probably a typical element of charms that were worn and used for the prevention of illness and misfortune. The firmest archaeological evidence to date for the presence of the evil eye belief at a single plantation has perhaps been recovered from the Hermitage in Nashville. In addition to a predominance of blue beads -25 of 71 beads, comprising 33 percent of the total bead sample - three brass figas, 
which figure prominently in the evil eye complex (Distasi 1981), have been recovered from slave residences (Smith 1976; McKee 1992; Russell 1996).

In addition possibly to being used to avert the evil eye, beads were also used to bring good luck and prevent illness. Former slave Mollie Dawson recalled, "Most all de young girls had what we called a charm string. Dey was a lot pettier den dese beads we buys at de store now. Dis charm string was suppose ter bring good luck ter de owner of it" (Singleton 1991:163). As late as the 1930s, African Americans continued to wear beads to prevent illness. This practice is illustrated by an elderly African-American woman photographed by a fieldworker with the Farm Services Administration. The photograph's caption states that the woman wore "black beads to prevent heart trouble" (Nixon 1938). Mrs. Holmes, from Amite County, Mississippi, remembers her grandfather praying on a long string of beads. He would then put one of the beads in a cup of tea which he said would cure rheumatism (Rawick 1972d:254).

Besides the use of beads in daily life, archaeologists have discovered beads in African-American interments. These mortuary contexts provide additional information concerning symbolic bead use. During the excavations at Parris Island, South Carolina, an African-American graveyard was encountered (South et al. 1988:163-165). This cemetery, called the Means Graveyard, was part of the Means Plantation which was occupied during the 18th and 19 th centuries. Within the graveyard, a pit containing charcoal and 3,481 glass beads, predominately blue and polychrome - blue, white, and coral-was found. Archaeologists found two more cremated, bead-filled pits located some distance from the African-American graveyard, but in the Means Plantation. These pits date between the late 17 th and 19 th centuries. By conducting interviews with members of the nearby African-modeled Yoruba ceremonial center, South was informed that West African inspired funerals involve two ceremonies, one in which the physical body is buried and another in which material possessions are cremated. South suggests these pits may represent the "practice of cremating material possessions", and offer firm ev- idence of African beliefs regarding the burial of the dead in the past (South et al. 1988:165).

In contrast to the Means Graveyard, most excavated African-American cemeteries do not contain very many beads. For example, excavation at seven cemeteries demonstrates burials containing beads average less than 5 percent of the total excavated burials (Handler and Lange 1978; Handler et al. 1979; Rose 1985; Parrington 1987; Watters 1987; Shogren et al. 1989; Cotter et al. 1992; LaRoche 1994). A good example of the mortuary distribution of beads is Elko Switch Cemetery which was in use between 1850 and 1920 . This cemetery contained relatively few graves with beads (4\% or two of 56 excavated burials). A middle-aged African-American woman over 50 years old (Burial 3), interred between 1850 and 1870, was buried with a necklace composed of 33 black wire-wound beads and one blue glass bead. Interestingly, the faceted blue bead was located in the center of the strand (Shogren et al. 1989:46-49, 143). Burial 24, an infant interred in 1895 , contained 300 clear glass beads. Twentyfour of the beads are large necklace beads, and the rest are seed beads. This burial contained an ornately decorated coffin (Shogren et al. 1989:9193).

Recently recovered information from the African Burial Ground in New York city also illustrates the persistence of African-derived cultural practices and bead use. Seven interments out of a sample of over 400 individuals contained beads. Interestingly, the burials containing beads were the remains of three women and two infants - the sex of the other two individuals was not determined. One woman exhibited dental mutilation, an African form of body decoration, and was buried with a waist strand composed of over 100 beads. One of the infants also possessed a waistlet. The beads associated with the other infant appear to have been worn in a necklace. The functional context of the beads interred with the other four individuals was not determined. Interestingly, blue and turquoise beads comprise 58 percent of the total sample (LaRoche 1994:3-20).

Mortuary information therefore illustrates beads were not typically an aspect of African-American burial practices. However, interments that do have beads appear to be associated more often with the 
graves of children, women, and conjurers (Handler et al. 1979; Rose 1985; Shogren et al. 1989; LaRoche 1994). Finally, although only quantifiable at the African Burial Ground, Newton, and Elko Switch cemeteries, blue beads in interments represent less than 30 percent of the beads by color. This distribution differs significantly with the number of blue beads (48\%) from African-American domestic contexts $\left(X^{2}=14.34, d f=1, p=<0.01\right)$. More detailed analysis of burial data could refine these insights, but in general it appears that different colors of beads may have been used in daily life and burial practices by African Americans.

Future archaeological research pertaining to bead use in both mortuary and daily life contexts should be conducted. This study examined only beads contained in published reports and books. In these reports the only consistently recorded bead attribute is color. Additional research should encompass the variables of manufacturing techniques, shape, diaphaneity, color, and size. A detailed comparison of bead data from cemeteries may reveal that age, gender, and status are important variables related to bead use.

\section{Color Symbolism}

Color symbolism is a central aspect of Central and West African religious beliefs (Farrow 1969; Janzen 1977, 1982; Gleason 1987). Concern with the spiritual qualities attributed to specific colors was also reestablished in the New World, in both South (Sturm 1977; Gleason 1987; Omari 1994) and North America. In North America, colors are often imbued with meaning in African-American traditions. Florida author Zora Neal Hurston (1978) writes in Mules and Men that 20th-century candle colors had symbolic meaning as follows: blue provided protection and success, or in an inversion could cause death. White was used for peace, weddings, or "to uncross"; red represented victory; pink, love and drawing away success; green aided success, or helped to "drive off' [haints]; yellow and brown brought money; lavender "caused harm"'; and black "always [represented] evil or death"' (Wahlman 1993:113). Color continues to be a key element in the modern novels of African-
American writers such as Toni Morrison. Baby Suggs in Beloved contemplates blue and yellow, because "that don't hurt nobody', (Morrison 1988: 179).

In studies of quilts made by African Americans in North Carolina, researchers found that strong, contrasting color choice was an important aesthetic (McDonald 1986:36, Roberson 1988:5). Twentiethcentury quilter Pecolia Warner used blue to symbolize truth, red for blood, white or silver for peace, yellow or gold for love, and brass for trouble. Black, although representing mourning in clothes, was used more for aesthetics by Warner as a contrast color in her quilts (Wahlman 1993:113). Various sources suggest that combined colors, such as red and white, in clothing and other textiles were often worn to ward away spirits (Wahlman 1993:113). In her folklore study of the Sea Islands, Twining (Wahlman 1993:113; 129 fn. 51) states that four colors - blue, black, red, and white - are "linked to a deeper set of values and meanings in culture." These colors are often used by African Americans in combinations that express binary oppositions such as good and bad or safe and dangerous. Color choice is important in African-American aesthetics, and certain colors used in specific contexts carry specific symbolic meaning.

The archaeological data compiled for this study clearly indicate that blue beads are the predominant bead color associated with African-American residences in the study area between the 18th and 19th centuries. It is, in turn, proposed that the predominance of blue beads at African-American slave sites was due to intentional selection. Their meaning reflects both aesthetics and religious beliefs. Blue beads were used as adornment and probably worn, in part, as amulets for protection from illness and misfortune. This interpretation is supported through consideration of the meaning attributed to the color blue in rural African-American belief systems. These belief systems are particularly apparent within folklore and art.

A wide array of items were used to make charms in the Southeast, and the color blue was commonly used for items incorporated into personal charms. Concerning the qualities attributed to the colors used in charms, a sheriff in the Beaufort area of 
South Carolina in the late 1960s wrote that root doctors "deal in tokens or charms of varying colors, and powders. A token of one color may cast a spell while another color is reputed to take it off", (McTeer 1970:72). Further, the Beaufort sheriff noted that blue charms are used for protection against evil and misfortune (McTeer 1970:24). In the South, powdered blue glass and bluestones were used in charms (Botkin 1966[1949]:632; Rawick 1972e:34; Puckett 1975:237, 240), blue ribbons are used in love charms (Hughes and Bontemps 1958: 194; Hurston 1978:283), and according to McTeer (1970:24) blue amulets are often used for romance. Jay Mills (1991, pers. comm.) has collected similar African-American oral histories about the importance of blue for protection and blessings in the Carolina Lowcountry.

In addition to personal charms, household charms and furnishings that contained the color blue were also used to protect the residences of rural African Americans. For example, in South Carolina and Georgia, African Americans in the past and present sometimes paint the attic louvers, gables, doors, and window molding blue for protection from spirits and witches (Folklore Project [1930s]: 1655, D-4-27A(1), D-4-27B(1); 1885, D-4-27A, F-2-18A; Crum 1968:85; Joyner 1984:153; Creel 1988:321; Conroy 1990:29; Wahlman 1993:113). During the 1930s, C. S. Murray, a Folklore Project writer, recorded that

\footnotetext{
The color blue is a sure charm against both ghosts and lightning, the Sea Island negroes hold. This is one reason why the doors and windows of almost every negro cabin are painted bright blue ... ghosts are afraid of this particular color because it reminds them of heaven. . . . They cannot face the sunlight, and neither can their eyes bear the sight of the color blue, for blue is the color of heavens. . . Lightning too is an evil spirit. Holy blue has the power to divert it from harm, if the bolt should enter the cabin while the doors and windows are open and the blue charm is temporarily hidden. In fact the color blue is a charm against almost any kind of evil, for the negroes like to think God himself prefers blue. (Folklore Project [1930s]:1655, D-4-27A).
}

Concerning this practice, Creel likewise states that

interviewers for the Federal Writers Project observed that nearly all the doors and windows of Gullah cabins were painted blue, the color of the heavens. One theory was that the custom of painting doors and windows blue was an unconscious holdover from the early days of slavery in the Sea Islands when Gullahs were given the residue from indigo vats to use on the doors and windows of their cabins. However, this does not explain the fact that Gullah conjurers concocted pills for their patients, the color of which was usually blue also. Perhaps then, the shade blue was effective in keeping out spirits (Creel 1988:321).

A resident of Georgia recently stated he still trims his house in this color to honor his elders' beliefs that they warded their homes from spirits by " painting the shadows"' (Joel Jones 1994, pers. comm.). Mrs. Elizabeth Porcher Mahoney, a native of Porcher's Bluff near Mt. Pleasant, South Carolina, also indicated that the blue trim around many local residences was to "keep out the hags" or witches (Elizabeth Porcher Mahoney 1995, pers. comm.). Mailboxes painted blue are also thought to keep away bad news (Steen 1992:53). Within the house, blue candles for furnishings are thought to provide success and protection (Hurston 1978:287). Similarly, when houses are cleaned, blue-colored scrub water is sometimes used to protect the residents (Hurston 1978:284, 286).

Bottle trees can be seen in Alabama, Georgia, Louisiana, and Mississippi. Brightly colored bottles, often blue, serve as protection from spirits (Melissa Beasley and John Cottier 1994, pers. comm.). Bottle trees, mirrors, and other objects could bless the person of good heart, or drive away those of evil intent (Thompson 1993:82-83; Vernon 1993:158). On a recent trip through Cleveland, Alabama, a decorated bottle tree placed in an AfricanAmerican man's backyard was observed. Blue painted Clorox bottles were hung on a tree close to the property's boundary with a cemetery (Stine 1994, pers. observation). In a number of illustrations of African-American yards and graves blue is likewise a prevalent color (Thompson 1993:79, 86 Plates 70, 71, 72; 91 Plates 62, 83; 94 Plate 93).

\section{Conclusion}

Through consideration of archaeological, ethnographic, and historical information, the preceding study attempted to demonstrate that blue beads served as both jewelry for personal adornment and 
charms among African Americans. Concerning general trends, several observations are apparent. Analysis of archaeological data demonstrated that blue is the predominant color of beads recovered from African-American domestic sites occupied during the colonial and antebellum periods in South Carolina and Georgia. Archaeological data clearly indicate that while only a few beads are typically recovered at African-American sites and cemeteries, the differences in color distributions are significant. For the entire South Carolina and Georgia site sample, blue beads comprise 36 percent, or represent on average eight beads per site. Mortuary data indicate beads are usually associated with women and infants, which parallel the preventive role of beads in West and Central Africa. Ethnographic information and folklore studies also demonstrate a strong degree of continuity existed between African Americans and their West and Central African predecessors in both their general animistic belief systems and the use of charms to influence the world they perceived. Archaeologically derived interpretations are supported by historical observations and folklore.

Our interpretation described the distribution of a specific artifact type and the beliefs, or emic worldview, possibly expressed by these artifacts. However, information presented in this essay has archaeological and anthropological relevance concerning historical processes of cultural continuity and change that extend beyond an artifact study. Diverse Central and West African groups exhibited staggering variation in material culture related to ornamentation and associated belief systems. Within the colonial and antebellum South an amalgam of West and Central African groups were forced to survive in a new and often hostile setting. A consequence of this experience was that previous and specific cultural elements were selected, rejected, modified, and magnified by African Americans and a largely uniform African-American culture emerged, particularly along coastal South Carolina and Georgia.

The pervasive aspect of blue within the AfricanAmerican worldview and material domain illustrates this process. From a multitude of cultural traditions and possibilities, African Americans along the Sea Islands of South Carolina and Georgia apparently selected blue as a socially meaningful cultural element. The symbolic role of this color, in the absence of clear African parallels, possibly represents the development of a uniquely AfricanAmerican practice. The underlying reasons why this color was specifically selected are unknown, yet research conducted by psychologists indicates blue exhibits beneficial, curative qualities and has been used around the world to prevent illness and cure diseases (Birren 1961[1950]:37, 57, 109, 260, 1978:95; Mahnke and Mahnke 1987:13). These qualities parallel the role of blue as a form of protection from misfortune and sickness documented in the South. The selection of this culturally meaningful element was in turn amplified and expressed within the material domain of rural African Americans between the 18 th and 20 th centuries. This folk belief also persisted differentially to the present. Ex-slave Callie Elder stated that blue beads had no particular meaning but were merely for decoration. Conversely, former slave Mollie Dawson recalled that beads were worn for good luck. The elderly African-American woman photographed in the 1930s stated that black beads were worn to prevent heart trouble. These examples illustrate that the folk beliefs considered in this essay persisted among some African-American people and not others in the South. The meaning attributed to blue survived in several material domains, yet was lost or forgotten in others, such as the realm of personal ornamentation. Oral history and folklore reveal that quilts, window trim, scrub water, mailboxes, and candles were imbued with the beneficial quality attributed to blue. The prevalence of blue beads at African-American sites offers compelling evidence these items were likewise vested with this characteristic during the colonial and antebellum periods.

\section{ACKNOWLEDGMENTS}

Earlier versions of this paper were presented in 1994 at the annual meetings of the Southeastern Archaeological Conference in Lexington, Kentucky, and the American Anthropological Association in Atlanta, Georgia. The authors thank Christopher De- 
Corse, Leland Ferguson, and Jay Mills for constructive suggestions on the subject. We also thank Thomas Wheaton for including the bead survey form in African-American Archaeology and appreciate the response from the newsletter's readers. Keith Derting of the South Carolina Institute of Archaeology and Anthropology was instrumental in helping locate reports and site information that formed the basis of the data set. Support for this study was provided by the Savannah River Archaeological Research Program. The authors assume responsibility for any errors in the essay.

\section{REFERENCES}

\section{ADAMS, NATAliE}

1993 Archaeological Investigations at 38GE377: Examination of a Deep Creek Phase Site and a Portion of the Eighteenth-Century Midway Plantation. Research Series 37. Chicora Foundation, Columbia, South Carolina

ADAMS, WILliam H. (EDITOR)

1987 Historical Archaeology of Plantations at Kings Bay, Camden County, Georgia. Reports of Investigations 5. Prepared by the Department of Anthropology, University of Florida, Gainesville. Submitted to the Naval Submarine Base, Kings Bay, Georgia.

ARMSTRONG, DOUGLAS

1990 The Old Village and the Great House: An Archaeological and Historical Examination of Drax Hall Plantation, St. Ann's Bay, Jamaica. University of Illinois Press, Chicago.

AsChER, Robert, AND Charles H. FairbanKS

1971 Excavations of a Slave Cabin: Georgia, U.S.A. Historical Archaeology 5:3-17.

Awolalu, J. O.

1979 Yoruba Beliefs and Sacrificial Rites. Longman Group Limited, Burnt Mill, United Kingdom.

BABSON, DAVID W.

1989 Pillars on the Levee: Archaeological Investigations at Ashland-Belle Helene Plantation, Geismar, Ascension Parish, Louisiana. Report prepared by Midwestern Archaeological Research Center, Normal, Illinois. Submitted to Division of Archaeology, Louisiana Department of Culture, Recreation, and Tourism, Baton Rouge.

BAUDin, REv. P

1885 Fetichism and Fetich Worshipers. Benziger Brothers, New York.

Bell, ElizaBeth Y.

1994 Buttons as Reflections of Plantation Culture. Paper presented at the Annual Meeting of the Southeastern and Midwestern Archaeological Conference, Lexington, Kentucky.

Berlin, Ira, AND Phillips A. Morgan (editors)

1990 The Slaves' Economy: Independent Production by Slaves in the Americas. Frank Cass, London.

BIRREN, FABER

1961 Color and Psychology and Color Therapy: A Factual Study of the Influence of Color on Human Life. Reprint of 1950 edition. University Books, Secaucus, New Jersey.

1978 Color and Human Response. Van Nostrand Reinhold, New York.

BLASSINGAME, JOHN W.

1974 The Slave Community: Plantation Life in the Antebellum South. Reprint of 1972 edition. Oxford University Press, New York.

BotKIN, B. A.

1966 A Treasury of Southern Folklore: Stories, Ballads, Traditions, and Folkways of the People of the South. Reprint of 1949 edition. Crown, New York.

Braund, Kathryn E. Holland

1993 Deerskins and Duffels: The Creek Indian Trade with Anglo-America, 1685-1815. University of Nebraska Press, Lincoln.

Brockington, P., M. Scardaville, P. Garrow, D. Singer, L. FranCE, AND C. Holt

1985 Rural Settlement in the Charleston Bay Area: Eighteenth- and Nineteenth-Century Sites in the Mark Clark Expressway Corridor. Report prepared by Garrow and Associates, Atlanta, Georgia. Submitted to South Carolina Department of Highways and Public Transportation, Columbia.

BURTON, RICHARD F.

1864 A Mission to Gelele, King of Dahome. Tinsley Brothers, London.

CAMPBell, JohN

1990 As "A Kind of Freeman"?: Slaves' Market-Related Activities in the South Carolina Upcountry, 18001860. In The Slaves' Economy: Independent Production by Slaves in the Americas, edited by Ira Berlin and Phillips A. Morgan, pp. 131-169. Frank Cass, London.

CARNeS, Linda F.

1984 Archaeological Investigations of Third Halifax Jail, Historic Halifax. North Carolina Historic Sites Division, Department of Cultural Resources, Raleigh.

1987 Euroamerican Artifacts from the Fredricks, Wall, and Mitchum Sites. In The Siouan Project: Seasons I and II, edited by Roy S. Dickens, Jr., H. Trawick Ward, 
and R. P. Steven Davis, Jr. Research Laboratories of Anthropology Monograph 1:141-165. University of North Carolina, Chapel Hill.

CARRILlo, Richard F.

1980 Green Grove Plantation: Archaeological and Historical Research at the Kinlock Site (38CH109), Charleston County. Report submitted to South Carolina Department of Highways and Public Transportation, Columbia.

COKER, William S.

1976 Entrepreneurs in the British and Spanish Floridas, 1775-1821. In Eighteenth-Century Florida and the Caribbean, edited by Samuel Proctor, pp. 15-39. University Presses of Florida, Gainesville.

COKer, William S., AND Thomas D. WATSON

1986 Indian Trader of the Southeastern Spanish Borderlands: Panton, Leslie and Company and John Forbes and Company, 1783-1847. University of West Florida Press, Pensacola.

CONROY, PAT

1990 The Water Is Wide. Reprint of 1972 edition. Old New York Book Shop Press, Atlanta, Georgia.

COTTER, JoHN L., DANIEL G. ROBERTS, AND

MICHAEL PARRINGTON

1992 The Buried Past: Archaeological History of Philadelphia. University of Pennsylvania Press, Philadelphia.

COURLANDER, HAROLD

1975 A Treasury of African Folklore: The Oral Literature, Traditions, Myths, Legends, Epics, Tales, Recollections, Wisdoms, Sayings, and Humor of Africa. Crown, New York.

Crane, Veron W.

1928 The Southern Frontier, 1670-1732. Duke University Press, Durham, North Carolina.

CRASS, DAVId C., AND MARK J. BROOKS (EDITORS)

1995 Cotton and Black Draught: Consumer Behavior on a Postbellum Farm. Savannah River Archaeological Research Papers 4. South Carolina Institute of Archaeology and Anthropology, University of South Carolina, Columbia.

Creel, Margaret Washington

1988 “A Peculiar People"': Slave Religion and Community-Culture Among the Gullahs. New York University Press, New York.

CRUM, MASON

1968 Gullah: Negro Life in the Carolina Sea Islands. Negro Universities Press, New York.

$\rightarrow$ Davison, Claire, Robert Giauque, AND

DESMOND CLARK

1971 Two Chemical Groups of Diachronic Glass Beads from West Africa. Man 6(4):645-659.
DECORSE, CHRISTOPHER

1989 Beads as Chronological Indicators in West African Archaeology: A Reexamination. Beads: Journal of the Society of Bead Researchers 1:41-54.

[1997] Oceans Apart: African Perspectives on New World Archaeology. In "I, too, Am America”: Studies in African American Archaeology, edited by Theresa A. Singleton. University Press of Virginia, Charlottesville, forthcoming.

DE MAREeS, Pieter

1987 Description and Historical Account of the Gold Kingdom of Guinea (1602), translated by Albert van Dantzig and Adams Jones. Oxford University Press, New York.

DEVore, STEPHEN LEROY

1992 Beads of the Bison Robe Trade: The Fort Union Trading Post Collection. Friends of Fort Union Trading Post, Williston, North Dakota.

DISTASI, LAWRENCE

1981 Mal Occhio [evil eye]: The Underside of Vision. North Point Press, San Francisco, California.

DRUCKER, LESLEY M., AND RONALD W. ANTHONY

1979 The Spiers Landing Site: Archaeological Investigations in Berkeley County, South Carolina. Report prepared by Carolina Archaeological Services, Columbia, South Carolina. Submitted to U.S. Department of Interior, Heritage Conservation and Recreation Services, Interagency Archaeological Service, Atlanta, Georgia.

DUBIN, LoIS

1987 The History of Beads: From 30,000 B.C. to the Present. Harry N. Abrams, New York.

DUNDES, ALAN (EDITOR)

1981 The Evil Eye: A Folklore Casebook. Garland, New York.

Ellis, A. B.

1894 The Yoruba-Speaking Peoples of the Slave Coast of West Africa. Chapman and Hall, London.

1964 The Tshi-Speaking Peoples of the Gold Coast of West Africa. Reprint of 1897 edition. Benin Press, Chicago, Illinois.

1970 The Ewe-Speaking Peoples of the Slave Coast of West Africa. Reprint of 1890 edition. Anthropological Publications, The Netherlands.

ERIKSON, JOAN M.

1969 The Universal Bead. W. W. Norton, New York.

ESCOTT, PAUL D.

1979 Slavery Remembered; A Record of Twentieth-Century Slave Narratives. University of North Carolina Press, Chapel Hill.

ESPENSHADE, CHRISTOPHER, AND RAMONA GRUNDEN 1991 Contraband, Refuge, and Freedman: Archaeological 
and Historical Investigations of the Western Fringe of Mitchelville, Hilton Head Island, South Carolina. Report prepared by Brockington and Associates, Atlanta, Georgia. Submitted to Greenwood Development Corporation, Hilton Head Island, South Carolina.

Eubanks, Elise, Christopher Espenshade, MARION ROBERTS, AND LINDA KENNEDY

1994 Data Recovery Investigations of 38BU791, Bonny Shore Slave Row, Spring Island, Beaufort County, South Carolina. Report on file, Brockington and Associates, Atlanta, Georgia.

FAGE, J. D.

1962 Some Remarks on Beads and Trade in Lower Guinea in the Sixteenth and Seventeenth Centuries. Journal of African History 3(2):343-347.

FARROW, STEPHEN S.

1969 Faith, Fancies and Fetich or Yoruba Paganism. Reprint of 1926 edition. Negro Universities Press, New York.

\section{FERGUSON, LELAND}

1992 Uncommon Ground: Archaeology and Early African America, 1650-1900. Smithsonian Institution Press, Washington, D.C.

FinCHER, JOSEPH TRAVIS

1871 Account Book of Mr. Joseph Travis Fincher of Pike County, Georgia. On file with Fincher's great-granddaughter, Linda Fincher Wood, Birmingham, Alabama.

FISHER, ANGELA

1984 Africa Adorned. Harry N. Abrams, New York.

FOLKLORE PROJECT

[1930s]Folklore Project, Works Progress Administration, No. 1655, D-4-27A(1), D-4-27B(1); No. 1885, D-4-27A, F-2-18A. Manuscripts Division, South Caroliniana Library, University of South Carolina, Columbia.

$\rightarrow$ FrazIER, E. FRANKLIN

1930 The Negro Slave Family. Journal of Negro History 15(2):198-259.

GARDNER, JEFFREY W.

1987 The Hunter's Hill Project: Historical and Archaeological Research at the Shute-Turner Farm, Davidson County, Tennessee. Ladies Hermitage Association, The Hermitage, Hermitage, Tennessee.

1992 Historic Adaptations Through Time: Archaeological Testing of Five Sites, Francis Marion National Forest, Berkeley and Charleston Counties, South Carolina. Report prepared by Brockington and Associates, Charleston, South Carolina. Submitted to the U.S.D.A. Forest Service, Francis Marion National Forest, Columbia, South Carolina.
GARDNER, JEFFREY W., AND ERIC POPLIN

1992 Wappo Plantation (38CH1 199/1200): Data Recovery at an Eighteenth-Century Stono River Plantation in Charleston County, South Carolina. Report prepared by Brockington and Associates, Charleston, South Carolina. Submitted to the U.S.D.A., Agriculture Research Service, South Atlantic Area, and U.S. Vegetable Laboratory, Charleston, South Carolina.

\section{GARROW, PATRICK}

1994 Postbellum Life on Hilton Head Island: The Frazier Cabin Site. Paper presented at the Annual Meetings of Southeastern Archaeological Conference and Midwest Archaeological Conference, Lexington, Kentucky.

\section{GASPER, DAVID BARRY}

1991 Antiqua Slaves and Their Struggle to Survive. In Seeds of Change: A Quincentennial Commemoration, edited by Herman J. Viola and Carolyn Margolis, pp. 130-138. Smithsonian Institution Press, Washington, D.C.

GenOVESE, EuGENE D.

1974 Roll, Jordan, Roll: The World the Slaves Made. Vintage Books, New York.

GLEASON, JUDITH

1987 Oya: In Praise of the Goddess. Shambhala, Boston, Massachusetts.

GOOD, MARY E.

1976 Glass Beads from the First Hermitage. In An Archaeological and Historical Assessment of the First Hermitage, edited by Samuel D. Smith. Research Series 2:237-248. Division of Archaeology, Tennessee Department of Conservation, Nashville, and Ladies Hermitage Association, The Hermitage, Hermitage, Tennessee.

1983 A Comparison of Glass Beads from Upper Creek Indian Towns in the Southeast and in Oklahoma. Proceedings of the 1982 Glass Trade Bead Conference, Rochester Museum and Science Center Research Records 16:159-166. Charles F. Hayes III, editor. Rochester, New York.

Groover, MARK D.

1992 Of Mindset and Material Culture: An Archaeological View of Continuity and Change in the 18th-Century South Carolina Backcountry. Volumes in Historical Archaeology 20, edited by Stanley South. South Carolina Institute of Archaeology and Anthropology, University of South Carolina, Columbia.

HAmell, GeORge R.

1983 Trading in Metaphors: The Magic of Beads. Proceedings of the 1982 Glass Trade Bead Conference, Rochester Museum and Science Center Research Records 16:5-28. Charles F. Hayes III, editor. Rochester, New York. 
HANDLER, JEROME S., AND FREDERICK W. LANGE

1978 Plantation Slavery in Barbados: An Archaeological and Historical Investigation. Harvard University Press, Cambridge, Massachusetts.

HANDler, Jerome S., Frederick W. LANGe, AND

CHARlES E. ORSER

1979 Carnelian Beads in Necklaces from a Slave Cemetery in Barbados, West Indies. Ornament 4(2):15-18.

HARRIS, ELIZABETH

1984 Late Beads in the African Trade. Archaeological Research Booklets 19. Center for Books on Beads, G. B. Fenstermaker, Lancaster, Pennsylvania.

HEATH, BARBARA J.

1994 An Interim Report on the 1993 Excavations: The Quarter Site at Poplar Forest, Forest, Virginia. Manuscript on file, Poplar Forest State Historic Site, Poplar Forest, Virginia.

HeRsKovits, MELVILle J.

1962 The Myth of the Negro Past. Reprint of 1941 edition. Beacon Press, Beacon Hill, Boston, Massachusetts.

HOEBEL, E. ADAMSON

1966 Anthropology: The Study of Man. McGraw-Hill, New York.

Hughes, LANGSTON, AND ARNA BONTEMPS

1958 The Book of Negro Folklore. Dodd, Mead, New York.

Hughes, LANGSTON, AND MILTON MELTZER (EDITORS)

1968 A Pictorial History of the Negro in America. Third edition, revised by C. Eric Lincoln and Milton Meltzer. Crown, New York.

Hurston, ZORA NEALE

1978 Mules and Men. Indiana University Press, Bloomington.

JANZEN, JOHN M.

1977 The Tradition of Renewal in Kongo Religion. In African Religions: A Symposium, edited by Newell $\mathrm{S}$. Booth, Jr., pp. 69-116. NOK, New York.

1982 Lemba, 1650-1930: A Drum of Affliction in Africa and the New World. Garland, New York.

Johnson, Thomas L., AND Phillips C. DunN

(COMPILERS)

1986 A True Likeness: The Black South of Richard Samuel Roberts; 1920-1936. Bruccoli Clark, Columbia, and Algonquin Books, Chapel Hill, South Carolina.

Jones, Olive, AND CATHERINE Sullivan

1989 The Parks Canada Glass Glossary for the Description of Containers, Tableware, Flat Glass, and Closures. Studies in Archaeology, Architecture, and History. Environment Canada-Parks, Ottawa, Ontario.

JOSEPH, J. W.

1987 Highway 17 Revisited: The Archaeology of Task Labor in the Lowcountry of Georgia and South Carolina.
Paper presented at the Annual Meeting of the Society for Historical Archaeology Conference on Historical and Underwater Archaeology, Savannah, Georgia.

JOYNER, CHARLES

1984 Down by the Riverside: A South Carolina Slave Community. University of Illinois Press, Chicago.

Kalous, Milan

1979 Akorite? Journal of African History 20:203-217.

KARKLINS, KARLIS

1985 Glass Beads: The 19th-Century Levin Catalogue and Venetian Bead Book and Guide to Description of Glass Beads. Studies in Archaeology, Architecture, and History. Environment Canada-Parks, Ottawa, Ontario.

KARKLINS, KARLIS, AND NORMAN BARKA

1989 The Beads of St. Eustatius, Netherlands Antilles. Beads: Journal of the Society of Bead Researchers 1:55-80.

Kelso, William M.

1984 Kingsmill Plantations, 1619-1800; Archaeology of Country Life in Colonial Virginia. Academic Press, New York.

KenNEDy, Linda, CHRISTOPHER T. EsPENSHADE, AND RAMONA GRUNDEN

1991 Archaeological Investigations of Two Turn-of-theCentury Farmsteads (38BU966 and 38BU967), Hilton Head Island, South Carolina. Report prepared by Brockington and Associates, Atlanta, Georgia. Submitted to the Greenwood Development Corporation, Hilton Head Island, South Carolina.

KENNEDY, Linda, MARION D. ROBERTS, AND

CHRISTOPHER T. ESPENSHADE

1993 Archaeological Data Recovery at River Club (38BU880), Hilton Head Island. Beaufort County: A Study in Late Eighteenth-/Early Nineteenth-Century African-American Lifeways. Report on file, Brockington and Associates, Atlanta, Georgia.

1994 Archaeological Data Recovery at Colleton River Plantation (38BU647), Hilton Head Island, Beaufort County, South Carolina: A Study of an Early 19thCentury Slave Settlement. Report on file, Brockington and Associates, Atlanta, Georgia.

KenYon, IAN, AND Thomas KenYon

1983 Comments on Seventeenth-Century Glass Trade Beads from Ontario. Proceedings of the 1982 Glass Trade Bead Conference, Rochester Museum and Science Center Research Records 16:59-74. Charles F. Hayes III, editor. Rochester, New York.

KERNAN, MiCHAEL

1993 The Object at Hand. Smithsonian 20:30-32. 


\section{KIDD, KENNETH E.}

1970 Glass Bead-making from the Middle Ages to the Early 19th Century. History and Archaeology 30. Ottawa.

KINGSLEY, MARY H.

1897 Travels in West Africa. Macmillan, New York.

LANDEWIJK, J. E. J. M. VAN

1970 What Was the Original Aggrey Bead (a New Aggrey Bead Hypothesis)? Ghana Journal of Sociology 6(2): 89-99.

LANGE, FREDERICK W., AND JEROME S. HANDLER

1985 The Ethnohistorical Approach to Slavery. In The Archaeology of Slavery and Plantation Life, edited by Theresa Singleton, pp. 15-32. Academic Press, New York.

LAROCHE, CHERYL J.

1994 Beads from the African Burial Ground, New York City: A Preliminary Assessment. Beads: Journal of the Society of Bead Researchers 6:3-20.

LEFLER, HUGH TALMAGE (EDITOR)

1967 A New Voyage to Carolina by John Lawson. University of North Carolina Press, Chapel Hill.

LiTTLEFIELD, DANIEL C.

1981 Rice and Slaves: Ethnicity and the Slave Trade in Colonial South Carolina. Louisiana State University Press, Baton Rouge.

Logan, Michael H., and Douglas A. Schmittou

1995 With Pride They Made These: Tribal Styles in Plains Indian Art. Occasional Paper 12. Frank H. McClung Museum, University of Tennessee, Knoxville.

LOWIE, ROBERT H.

1924 Primitive Religion. Boni and Liveright, New York.

MACDONALD, GEORGE

1969 The Gold Coast, Past and Present: A Short Description of the Country and Its People. Negro Universities Press, New York.

MahnKe, Frank H., AND Rudolf H. MaHNKE

1987 Color and Light in Man-Made Environments. Van Nostrand Reinhold, New York.

Maloney, Clarence (EDITOR)

1976 The Evil Eye. Columbia University Press, New York.

MCDONALD, MARY ANNE

1986 Jennie Burnett: Afro-American Quilt Maker. In Five North Carolina Folk Artists, edited by Charles G. Zug III, pp. 27-39. Ackland Art Museum, University of North Carolina Press, Chapel Hill.

MCDONALD, RODERICK A.

1990 Independent Economic Production by Slaves on Antebellum Louisiana Sugar Plantation. In The Slaves' Economy: Independent Production by Slaves in the Americas, edited by Ira Berlin and Phillips A. Morgan, pp. 182-208. Frank Cass, London.
MCKeE, LARRY

1992 Summary Report on the 1991 Hermitage Field Quarter Excavation. Tennessee Anthropological Association Newsletter 18(1):1-17.

MCTeER, J. E.

1970 High Sheriff of the Low Country. Beaufort Books, Beaufort, South Carolina.

MerRell, JAMES $\mathrm{H}$.

1991 The Indians' New World: Catawbas and Their Neighbors from European Contact Through the Era of Removal. Second edition. W. W. Norton, New York and London.

MiCHIE, JAMES L.

1987 Richmond Hill and Wachesaw: An Archaeological Study of Two Rice Plantations on the Waccamaw River, Georgetown County, South Carolina. Research Manuscript Series 203. South Carolina Institute of Archaeology and Anthropology, University of South Carolina, Columbia.

Michie, James L., AND Jay Mills

1988 The Search for Architectural Remains at the Planter's House and the Slave Settlement, Richmond Hill Plantation, Georgetown County, South Carolina. Research Manuscript Series 205. South Carolina Institute of Archaeology and Anthropology, University of South Carolina, Columbia.

Miller, Henry, DenNis Pogue, AND

MiCHAEL SMOLEK

1983 Beads from the Seventeenth-Century Chesapeake. Proceedings of the 1982 Glass Trade Bead Conference, Rochester Museum and Science Center Research Records 16:127-144. Charles F. Hayes III, editor. Rochester, New York.

Milligan, Robert H.

1912 The Fetish Folk of West Africa. Fleming H. Revell, New York.

MinTZ, SidNEY W., AND Douglas Hall

1960 The Origins of the Jamaican Internal Marketing System. In Papers in Caribbean Anthropology 57, edited by Sidney W. Mintz. Yale University Publications in Anthropology, New Haven.

MOORE, N. HUDSON

1924 Old Glass: European and American. Tudor, New York.

MORRISON, TONI

1988 Beloved. Plume Contemporary Fiction, New York.

NASSAU, ROBERT H.

1904 Fetishism in West Africa. Charles Scribner's Sons, New York.

1969 Fetishism in West Africa. Negro Universities Press, New York. 
Nixon, Herman Clarence

1938 Forty Acres and Steel Mules. University of North Carolina Press, Chapel Hill.

Norrell, Robert J., AND CATHerine C. MEYer

1992 History and Archaeology of Nineteenth-Century Alabama. Report of Investigations 64. Report prepared by Division of Archaeology, University of Alabama, Alabama Museum of Natural History. Submitted to Transcontinental Gas Pipe Line Corporation of Houston, Texas.

Nourisson, Pascale

1992 Beads in the Lives of the People of Southern Togo, West Africa. Beads: Journal of the Society of Bead Researchers 4:29-38.

O'MALLEY, NANCY

1995 Archaeological Investigations in Kinkeadtown, a Post-Civil War African-American Neighborhood in Lexington, Kentucky. Department of Anthropology, University of Kentucky, Lexington.

OMARI, Mikelle SMITH

1994 Candomlé: A Socio-Political Examination of African Religion and Art in Brazil. In Religion in African Experience and Expression, edited by Thomas D. Blakely, Walter E. A. van Beek, and Dennis L. Thomson, pp. 135-159. Heinemann, Portsmouth, New Hampshire.

OPPER, MARIE-JoSe, AND HowARD OPPER

1989 Diakhite: A Study of the Beads from an 18th- to 19th-Century Burial Site in Senegal, West Africa. Beads: Journal of the Society of Bead Researchers 1:5-20.

ORSER, CHARLES E., JR.

1994 The Archaeology of African-American Slave Religion in the Antebellum South. Cambridge Archaeological Journal 4(1):33-45.

Orser, Charles E., Jr., AnNette M. Nekola, AND

JAMES L. ROARK

1987 Exploring the Rustic Life, Multidisciplinary Research at Millwood Plantation, a Large Piedmont Plantation in Abbeville County, South Carolina, and Elbert County, Georgia. Report prepared by Mid-American Research Center, Loyola University, Chicago, Illinois. Submitted to U.S. Army Corps of Engineers, National Park Service, Atlanta, Georgia.

OTTO, JoHn SOLOMON

1984 Cannon's Point Plantation, 1794-1860: Living Conditions and Status Patterns in the Old South. Academic Press, New York.

Paonessa, Laurie J., Scott K. Parker, AND

LYNNE G. LEWIS

1993 "I Was Born and Raised Here": Investigations at the
Bowens House Site, Drayton Hall, Spring 1992. $\mathrm{Na}$ tional Trust Archaeological Research Center, Monograph Series 6. Montpelier Station, Virginia.

PARRINDER, GEOFFREY

1957 African Traditional Religion. Hutchinson House, New York.

1961 West African Religion: A Study of the Beliefs and Practices of Akan, Ewe, Yoruba, Ibo, and Kindred Peoples. Epworth Press, London.

PARRINGTON, MichaEL

1987 Cemetery Archaeology in the Urban Environment: A Case Study from Philadelphia. In Living in Cities: Current Research in Urban Archaeology, edited by Edward Staski. Special Publication Series 5:48-55. The Society for Historical Archaeology, California, Pennsylvania.

PatTen, M. Drake

1992 Mankala and Minkisi: Possible Evidence of African American Folk Beliefs and Practices. African American Archaeology 6:5-7.

\section{PEAKE, ORA BROOKS}

1954 A History of the United States Indian Factory System, 1795-1822. Sage, Denver, Colorado.

PIPER, HARRY M., KeNNETH W. HARDIN, AND

JACQUELYN G. PIPER

1982 Cultural Responses to Stress: Patterns Observed in American Indian Burials of the Second Seminole War. Southeastern Archaeology 1(2):122-137.

PiPER, Harry M., AND JacQuelyn G. PIPER

1982 Archaeological Excavations at the Quad Block Site, 8-Hi-998; Located at the Site of the Old Fort Brooke Municipal Parking Garage, Tampa, Florida. Report on file, Piper Archaeological Research, St. Petersburg, Florida.

Pogue, Dennis J., AND Esther C. White

1991 Summary Report on the "House of Families" Slave Quarter Site (44 Fx 162/40-47). File Report 2. Report on file, Mount Vernon Ladies' Association, Mount Vernon Plantation, Mount Vernon, Virginia.

POLLITZER, W. S.

1975 The Negroes of Charleston (S.C.): A Study of Hemoglobin Types, Serology, and Morphology. In Man and Nature, Studies in the Evolution of the Human Species, edited by Frederick S. Hulse, pp. 266-283. American Book-Stratford Press, Brattleboro, Vermont.

Praetzellis, Mary, AND AdRian Praetzellis

1992 "We were there too": Archaeology of an AfricanAmerican Family in Sacramento, California. Report on file, Anthropological Studies Center, Sonoma State University, Rohnert, California. 
$\rightarrow$ PRICE, RICHARD

1966 Caribbean Fishing and Fishermen: A Historical Sketch. American Anthropologist 68:1363-1383.

PuCKETT, NeWBEll Niles

1975 Folk Beliefs of the Southern Negro. Reprint of 1926 edition. Negro Universities Press, New York.

PULSIPHER, LydiA M.

1990 They Have Saturdays and Sundays to Feed Themselves: Slave Gardens in the Caribbean. Expedition 32(2):24-33.

1991 Galways Plantation, Montserrat. In Seeds of Change: A Quincentennial Commemoration, edited by Herman J. Viola and Carolyn Margolis, pp. 139-159. Smithsonian Institution Press, Washington, D.C.

RATTRAY, R. S.

1923 Ashanti. Clarendon Press, Oxford.

1927 Religion and Art in Ashanti. Clarendon Press, Oxford.

RAWICK, GEORGE P.

1972a The American Slave: A Composite Autobiography. Vol. 6, Alabama and Indiana Narratives. Greenwood, Westport, Connecticut.

1972b The American Slave: A Composite Autobiography. Vol. 4, Texas Narratives, Parts 1 and 2. Greenwood, Westport, Connecticut.

1972c The American Slave: A Composite Autobiography. Vol. 12, Georgia Narratives, Parts 1 and 2. Greenwood, Westport, Connecticut.

1972d The American Slave: A Composite Autobiography, Supplement Series 1. Vol. 6, Mississippi Narratives, Part 1. Greenwood, Westport, Connecticut.

1972e The American Slave: A Composite Autobiography. Vol. 4, Georgia Narratives, Part 1. Greenwood, Westport, Connecticut.

RAWLEY, JAMES A.

1981 The Transatlantic Slave Trade: A History. W. W. Norton, New York and London.

ROBERSON, RUTH HAISLIP (EDITOR)

1988 North Carolina Quilts. North Carolina Quilt Project, University of North Carolina Press, Chapel Hill.

ROBERTSON, RoBERT ALEXANDER

1969 Chats on Old Glass. Dover, New York.

ROSE, JEROME C. (EDITOR)

1985 Gone to a Better Land: A Biohistory of a Rural Black Cemetery in the Post-Reconstruction South. Arkansas Archeological Survey Research Series 25. Arkansas Archeological Survey, Fayetteville.

Ross, Lester A.

1990 Trade Beads from Hudson's Bay Company, Fort Vancouver (1829-1860), Vancouver, Washington. Beads: Journal of the Society of Bead Researchers 2:29-68.
Russell, Aaron E.

1996 "Spiritual" Artifacts from Hermitage Slave Dwellings. Paper presented at the Annual Meeting of the Society for Historical Archaeology Conference on Historical and Underwater Archaeology, Cincinnati, Ohio.

SAMFORD, PATRICIA

1994 West African Cultural Traditions in the Archaeological Record. Paper presented at the Annual Meetings of the Southeastern Archaeological Conference and Midwest Archaeological Conference, Lexington, Kentucky.

1996 The Archaeology of African-American Slavery and Material Culture. William and Mary Quarterly, third series, 53(1):87-113.

SCHLOTTERBECK, JOHN T.

1990 The Internal Economy of Slavery in Rural Piedmont Virginia. In The Slaves' Economy: Independent Production by Slaves in the Americas, edited by Ira Berlin and Phillips A. Morgan, pp. 170-181. Frank Cass, London.

Shogren, Michael G., Kenneth R. Turner, And JODY C. PERRONI

1989 Elko Switch Cemetery: An Archaeological Perspective. Report of Investigations 58. Division of Archaeology, Alabama State Museum of Natural History, Moundville.

Singleton, Theresa A.

1991 The Archeology of Slave Life. In Before Freedom Came: African-American Life in the Antebellum South, edited by Edward D. C. Campbell, Jr., with Kym S. Rice, pp. 155-175. Museum of the Confederacy, Richmond, and University Press of Virginia, Charlottesville.

Singleton, Theresa A., AND MARK D. Bograd (COMPILERS)

1995 The Archaeology of the African Diaspora in the Americas. Guides to the Archaeological Literature of the Immigrant Experience in America 2. The Society for Historical Archaeology, California, Pennsylvania.

SMITH, MARVIN T.

1983 Chronology from Glass Beads: The Spanish Period in the Southeast, 1513-1670. Proceedings of the 1982 Glass Trade Bead Conference, Rochester Museum and Science Center Research Records 16:147-158. Charles F. Hayes III, editor. Rochester, New York.

1986 Archaeological Testing of Sites 2 and 3, Heritage Plantation, Georgetown County, South Carolina. Report prepared by Garrow and Associates, Atlanta, Georgia. Submitted to Heritage Plantation, Pawleys Island, South Carolina.

SMITH, MaRvin, AND MARY Elizabeth GoOD

1982 Early Sixteenth-Century Glass Beads in the Spanish Colonial Trade. Cottonlandia Museum, Greenwood, Mississippi. 
SMith, SAMUEL D.

1975 Archaeological Explorations at the Castalian Springs, Tennessee, Historic Site. Tennessee Historical Commission, Nashville.

1976 An Archaeological and Historical Assessment of the First Hermitage. Research Series 2. Tennessee Division of Archaeology, Nashville.

1977 Plantation Archaeology at the Hermitage: Some Suggested Patterns. Tennessee Anthropologist 2(2):152163.

\section{SOUTH, STANLEy, RuSSEll K. SKOWRONEK, AND}

\section{RICHARD E. JOHNSON}

1988 Spanish Artifacts from Santa Elena. Anthropological Studies 7. Occasional Papers of South Carolina Institute of Archaeology and Anthropology, University of South Carolina, Columbia.

STEEN, CARL

1992 A Preliminary Report on the 1992 Excavations at Pine Grove Plantation, Berkeley County, South Carolina. Report on file, Diachronic Research Foundation, Columbia, South Carolina.

1995 Archaeological Investigations at Somerset Plantation, Washington County, North Carolina. Report prepared by Diachronic Research Foundation, Columbia, South Carolina. Submitted to the North Carolina Historic Sites Division, Department of Cultural Resources, Raleigh, North Carolina.

\section{STEINER, CHRISTOPHER}

1990 West African Trade Beads: Symbols of Tradition. Ornament 14(1):58-61.

STINE, Linda FranCE

1989 Raised Up in Hard Times: Factors Affecting Material Culture on Upland Piedmont Farmsteads, circa 19001940s. Unpublished Ph.D. dissertation, Department of Anthropology, University of North Carolina, Chapel Hill.

1990 Mercantilism and Piedmont Peltry: Colonial Perceptions of the Southern Fur Trade, circa 1640-1740. Volumes in Historical Archaeology 14, edited by Stanley South. South Carolina Institute of Archaeology and Anthropology, Columbia.

1993 Archaeological Testing at the Saddlebag Cabin, Forks of Cypress Plantation, Lauderdale County, Alabama. Report prepared by RUST International, GIS Labs, Samford University, Birmingham, Alabama. Submitted to Heritage Preservation, Florence, Alabama.

Stine, Linda F., Paul Brockington, JR., AND CONNIE HUDDLESTON

1994 Searching for the Slave Village at Snee Farm Plantation: The 1987 Archaeological Investigations. Report prepared by Brockington and Associates, Atlanta, Georgia. Submitted to the Southeastern Regional Offices, National Park Service, Atlanta, Georgia.
STONE, LYLE M.

1974 Fort Michilmackinac, 1515-1781: An Archaeological Perspective on the Revolutionary Frontier. Publications of the Museum, Michigan State University, East Lansing.

\section{STURM, Fred GiLletTE}

1977 Afro-Brazilian Cults. In African Religions: A Symposium, edited by Newell S. Booth, Jr., pp. 217-240. NOK, New York.

THOMPSON, ERA BeLl

1954 Africa: Land of My Fathers. Doubleday, New York.

THOMPSON, ROBERT FARRIS

1993 Face of the Gods: Art and Altars of Africa and the African Americas. Museum for African Art, New York, and Prestel, Munich.

TINGLING, MARION (EDITOR)

1977 The Correspondence of the Three William Byrds of Westover, Virginia, 1684-1776. Virginia Historical Society, University Press of Virginia, Charlottesville.

TRINKLEY, MiCHAEL (EDITOR)

1986 Indian and Freedmen Occupation at the Fish Haul Site (38BU805), Beaufort County, South Carolina. Research Series 7. Chicora Foundation, Columbia, South Carolina.

1990 Archaeological Excavations at 38BU96, a Portion of Cotton Hope Plantation, Hilton Head Island, Beaufort County, South Carolina. Chicora Foundation, Columbia, South Carolina.

1991 Further Investigations of Prehistoric and Historic Lifeways on Callawassie and Spring Islands, Beaufort County, South Carolina. Research Series 23. Chicora Foundation, Columbia, South Carolina.

1993a The History and Archaeology of Kiawah Island, Charleston County, South Carolina. Research Series 30. Chicora Foundation, Columbia, South Carolina.

1993b Archaeological and Historical Examinations of Three Eighteenth- and Nineteenth-Century Rice Plantations on the Waccamaw Neck. Research Series 31. Chicora Foundation, Columbia, South Carolina.

TrinkLey, Michael, Natalie AdAMs, AND

DEBI HACKER

1992 Plantation Life in the Piedmont: A Preliminary Examination of Rosemont Plantation, Laurens County, South Carolina. Research Series 29. Chicora Foundation, Columbia, South Carolina.

\section{Trinkley, Michael, DeBI HaCKer, AND \\ NATALIE ADAMS}

1993 Life in the Pee Dee: Prehistoric and Historic Research on the Roche Carolina Tract, Florence County, South Carolina. Research Series 39. Chicora Foundation, Columbia, South Carolina. 
Vernon, Amelia Wallace

1993 African Americans at Mars Bluff, South Carolina. Louisiana State University Press, Baton Rouge.

Wahlman, Maude Southwell

1993 Signs and Symbols: African Images in African-American Quilts. Studio Books, Museum of American Folk Art, New York.

WALLIS, WILSON

1939 Religion in Primitive Society. F. S. Crofts, New York.

WARD, H. TRAWICK, AND R. P. STEPhENS DAVIS, JR.

1993 Indian Communities on the North Carolina Piedmont, A.D. 1000 to 1700 . Reprint of 1978 edition. Cleveland Museum of Art, Cleveland, Ohio.

WATTERS, DAVID R.

1987 Excavations at the Harney Site Slave Cemetery, Montserrat, West Indies. Annals of Carnegie Museum 56:289-318.

Wayne, Lucy B., And Martin F. Dickinson

1990 Four Men's Ramble: Archaeology in the Wando Neck, Charleston County, South Carolina. Report prepared by SouthArc, Gainesville, Florida. Submitted to Dunes West Development Corporation, Mount Pleasant, South Carolina.

WeEKS, William M.

1990 The John H. Allston House Site: An Initial Occupation of Richmond Hill Plantation, Georgetown County, South Carolina. Volumes in Historical Archaeology 10, edited by Stanley South. South Carolina Institute of Archaeology and Anthropology, University of South Carolina, Columbia.

\section{WEISMAN, BRENT RICHARDS}

1989 Like Beads on a String: A Culture History of the Seminole Indians in North Peninsular Florida. University of Alabama Press, Tuscaloosa.

WELTY, EUDORA

1989 Eudora Welty Photographs, forward by Reynolds Price. University Press of Mississippi, Jackson.

WeSley, Charles HaRris

1968 In Freedom's Footsteps: From the African Background to the Civil War. International Library of Negro Life and History. Publishers Company, New York.

\section{WHEATON, THOMAS R.}

1993 Archaeological Testing of Willow Hall and Walnut Grove Plantations, Francis Marion National Forest. Report prepared by New South Associates, Stone
Mountain, Georgia. Submitted to U.S.D.A. Forest Service, Francis Marion National Forest, Columbia, South Carolina.

\section{WheATON, ThOMAS R., AMY FRIEDLANDER, AND}

PATRICK GARROW

1983 Yaughan and Curriboo Plantations: Studies in AfroAmerican Archaeology. Report prepared by Soil Systems, Marietta, Georgia. Submitted to U.S. Army Corps of Engineers, Charleston District.

\section{White, Deborah GraY}

1991 Female Slaves in the Plantation South. In Before Freedom Came: African-American Life in the Antebellum South, edited by Edward D. C. Campbell, Jr., with Kym S. Rice, pp. 101-121. Museum of the Confederacy, Richmond, and the University Press of Virginia, Charlottesville.

WILKIE, LAURIE A.

1994 Archaeological Evidence of an African-American Aesthetic. African-American Archaeology 10:1, 4.

1995 Magic and Empowerment on the Plantation: An Archaeological Consideration of African-American Worldview. Southeastern Archaeology 14(2):136148.

WOOD, KAREN G.

1991 Site Evaluation on Three Sites at Historic Clayfield Plantation, Wambaw Ranger District, Francis Marion National Forest, South Carolina. Report prepared by Southeastern Archaeological Services, Athens, Georgia. Submitted to U.S.D.A, Forest Service, Francis Marion and Sumter National Forest, Columbia, South Carolina.

\section{Works Progress AdMINISTRATION (WPA)}

1974 Drums and Shadows: Survival Studies among the Georgia Coastal Negroes. Savannah Unit, Georgia Writers' Project, Work Projects Administration. Reprint of 1940 edition. Reprint Company, Spartanburg, South Carolina.

WRIGHT, J. LEITCH, JR.

1986 Creeks and Seminoles: The Destruction and Regeneration of the Muscogulge People. University of $\mathrm{Ne}$ braska Press, Lincoln.

YENTSCH, ANNE E.

1994a A Chesapeake Family and Their Slaves: A Study in Historical Archaeology. Cambridge University Press, Cambridge.

1994b Beads as Silent Witnesses of an African-American Past: Social Identity and the Artifacts of Slavery in Annapolis, Maryland. Paper presented at the Annual Meeting of the Society for Historical Archaeology Conference on Historical and Underwater Archaeology, Vancouver, British Columbia. 
YOUNG, AMY L.

1994 Change and Continuity in African-Derived Religious Practices on an Upland South Plantation. Paper presented at the 51st Southeastern Archaeological Conference, Lexington, Kentucky.

Zierden, Martha A., Jeanne Calhoun, and Debi HACKER-NORTON

1985 Archdale Hall: Investigations of a Low Country Plantation. Archaeological Contributions 10. Charleston Museum, Charleston, South Carolina.

Zierden, Martha A., LeSley M. DRUCKer, AND JEANNE CALHOUN

1986 Rural Life on Daniel's Island, Berkeley County, South Carolina. Report prepared by Carolina Archaeological Services, Columbia, and Charleston $\mathrm{Mu}$ seum, Charleston. Submitted to South Carolina Department of Highways and Public Transportation, Columbia.
LiNDA FRANCE STINE

1801 15TH STREET

Siler City, NoRTh Carolina 27344-2131

Melanie A. CABAK

Savannah River Archaeological Research PROGRAM

P. O. DRAWER 600

New Ellenton, South Carolina 29809-0600

MARK D. GROOVER

UNIVERSITY OF TENNESSEE

DEPARTMENT OF ANTHROPOLOGY

252 SOUTH Stadium HaLl

KNOXVILLE, TENNESSEE 37996-0720 